\author{
Dr. sc. Dejan Bodul, docent \\ Pravnog fakulteta Sveučilišta u Rijeci ${ }^{1}$
}

\title{
PLURALITET CILJEVA STEČAJNOG POSTUPKA
}

\author{
UDK: 347.7 \\ Primljeno: 10. 10. 2016. \\ Pregledni rad
}

Funkcionalizacija hrvatskog stečajnog prava (i postupka) mora se shvatiti kao širi proces od obične recepcije stranih pravnih instituta i ad hoc rješenja za saniranje trenutnih ekonomskih i socijalnih posljedica. Uzimajući u obzir eklektičnost pristupa izmjenama stečajnih propisa, opravdano je postaviti pitanje: koji je cilj stečajnog postupka i u čiju se korist on vodi? Navedeno posebno dolazi do izražaja jer se u praktičnoj primjeni propisa o stečaju ,prelamaju“ interesi više zainteresiranih sudionika (države, vjerovnika /običnih i privilegiranih/, radnika, stečajnih upravitelja, bivših vlasnika pa i širi društveni interesi). Stoga autor, analizirajući interese navedenih stranaka, tijela i sudionika stečajnog postupka, ukazuje na ograničene mogućnosti postizanja normativno definiranih stečajno-pravnih ciljeva. Svakako smatramo bitnim istaknuti kako prostor koji ovdje imamo ne dopušta detaljnu raščlambu ove problematike, pa smo prinuđeni isključivo se ograničiti, po mišljenju autora, na neke aspekte nove stečajne regulative koja najbolje definira predmet rada.

\section{Ključne riječi: novi stečajni propisi, zacrtani ciljevi, praktične implikacije propisa o stečaju}

\section{UMJESTO UVODA}

Uvaženo je stajalište teorije da insolvencijski/stečajni model u ukupnosti reflektira pravno, povijesno, političko i kulturno nasljeđe zemlje koja ga je razvila. ${ }^{2}$ Ipak, i

1 Pravni fakultet Sveučilišta u Rijeci, Katedra za građansko procesno pravo. Ovaj je rad nastao uz potporu Hrvatske zaklade za znanost u okviru projekta 6558 Business and Personal Insolvency - the Ways to Overcome Excessive Indebtednes.

2 Iako postoji mnoštvo članaka i knjiga koji dovode u vezu nacionalnu (pravnu i ekonomsku) kulturu s nizom ekonomskih ishoda, u ekonomskoj literaturi ne postoji eksplicitna analiza odnosa nacionalnih kultura na ishode u stečaju. Vidi, Armour, J., Cumming, D., „Bankruptcy law and entrepreneurship“, American Law and Economics Review, vol. 10, 2008., str. 303-350. Pravna literatura nešto je bogatija u pogledu analize odnosa između nacionalne kulture i stečajnog prava. Vidi Beugelsidjk, S, R. Maseland, R., Culture in Economics - History, Methodological Reflections and Contemporary Applications, Cambridge University Press, Cambridge UK, 2010.; Davydenko, S. A., Franks, J., „Do Bankruptcy Codes Matter? A Study of Defaults in France, Germany, and the U.K.", The Journal of Finance, vol. 63, 2008., str. 565608, te Martin, N., ,The Role of History and Culture in Developing Bankruptcy and Insolvency Systems: The Perils of Legal Transplantation“, Boston College International \& Comparative Law Review, vol. 28, 2005., no. 1, str. 1-78. Posljednjih godina, velik broj radova razmatrao je utjecaj pravnih tradicija na niz ekonomskih indikatora. Literatura posvećena utjecaju pravne tradicije zasnovana je na dvije pretpostavke. Prva je da se pravni okviri mogu klasificirati i mjeriti. Vidi Lee, S.-H., Yamakawa, Y., Peng, M., Barney, J., „How do bankruptcy laws affect entrepreneurship development around the world?“, Journal of Business Venturing, vol. 26, 2011., str. 505-520. Druga je pretpostavka da pravne tradicije značajno određuju izgled današnjeg pravnog okvira koji utječe na različite ekonomske ishode. Jedan od ekonomskih ishoda koji je razmatran u okviru navedene pretpostavke o značaju pravnih tradicija jest učinkovitost stečajnog okvira. 
zemlje koje dijele zajedničku pravnu tradiciju, primjerice, Sjedinjene Američke Države, Velika Britanija, Kanada, Australija i Novi Zeland, imaju značajne razlike u reguliranju instituta korporativnog, ali i potrošačkog stečaja. ${ }^{3}$ Navedena teza posebno dolazi do izražaja ako analiziramo zemlje s različitim pravnim tradicijama, poput onih u kontinentalnoj Europi (romanski, germanski ili anglosaksonski krug zemalja). ${ }^{4}$ Dakle, ostaje teza da postoje različita normativna uređenja stečajnih postupaka u raznim nadležnostima, slijedom čega se i neka temeljna pravila mogu značajno razlikovati od države do države. Štoviše, u pravnoj teoriji govori se čak i o „stečajnim kulturama“. 5 Međutim, iako postoje mnogobrojne definicije i različita viđenja stečaja, sva upućuju na osnovni cilj stečaja - stvaranje kolektivnog mehanizma kojim bi se stečajnim vjerovnicima pružila mogućnost da prepoznaju i odaberu najbolju strategiju za povrat iznosa koji im se duguju. ${ }^{6}$

\section{HRVATSKO STEČAJNO ZAKONODAVSTVO U KONTEKSTU „SUKOBA“ PROCESUALISTA I TRADICIONALISTA}

Već desetljećima, „tradicionalisti“ i ,procesualisti“ predstavljaju dva glavna pravca u području stečajnog prava, s različitim odgovorom na pitanje - koji je ratio stečajnog postupka. Za procesualiste, stečajni postupak bavi se isključivo obvezom razmjernog namirenja vjerovnika, čija je principijelna ravnopravnost (in concursu conditio omnium creditorum par est) relativizirana činjenicom postojanja isplatnih redova. ${ }^{7}$ Prepoznavanje i zakonsko definiranje primarnog interesa u stečajnom postupku - interesa vjerovnika, zadatak je i hrvatskog zakonodavca i judikature. Doprinos po tom pitanju daju i brojne međunarodne institucije kao što su OECD, ${ }^{8}$

Vidi Djankov, S., Hart, O., McLiesh, C., Shleifer, A., „Debt Enforcement Around the World“, Journal of Political Economy, vol. 116, 2008., str. 1105-1150, te Radulović, B., Jovanović, A.,, „Stečaj, poverenje i nacionalna kultura“, Ekonomska politika Srbije u 2015., B. Živković, B. Cerović (ured.), Ekonomski fakultet Univerziteta u Beogradu i Naučno društvo ekonomista Srbije, 2015., str. 133-152.

3 Vidi Martin, N., „Common-Law Bankruptcy Systems - Similarities and Differences“, American Bankruptcy Institute Law Review, vol. 11, 2003., str. 367.

4 Da bi se stekao uvid u kompleksnost materije stečajnog postupka u EU, dovoljno je reći kako su pri stvaranju Uredbe Vijeća (EC) broj 1346/2000, od 29. svibnja 2000. o stečajnim postupcima (OJ 2000 L 160) izmijenjene Uredbom 603/2005 od 12. travnja 2005. (OJ 2005 L 100) uvjetno rečeno, usuglašavana pravila iz 54 različita modela stečajnih postupaka. Podrobnije, Baltić, M., Načela evropskog stečajnog prava sa posebnim osvrtom na evropsku regulativu o stečajnim postupcima, Centar za pravo Evropske unije i Udruženje za pravo Evropske unije, Beograd, vol. 5, 2003., no. 1-3, str. 43-63.

5 Primjerice Virgos, M., The 1995 European Community Convention on Insolvency Proceedings: An Insider's View, Kluwer Law International, The Hague, 1998., str. 1. et seq.

6 Raymond Azar, Z., Ziad, „Bankruptcy Policy: A Review and Critique of Bankruptcy Statutes and Practices in Fifty Countries Worldwide“, Cardozo Journal of International and Comparative Law, vol. 16, 2008, no. 1, str. 282. et seq. te Claessens, S., Klapper, L. F., Bankruptcy around the World: Explanation of its Relative Use, World Bank Publicity Research Working Paper 2865., 2002.

7 Jackson, T. H., „Bankruptcy, Non-Bankruptcy Entitlements, and the Creditors’ Bargain“, Yale Law Journal, vol. 91, 1982., str. 857.

8 OECD, Creditor Rights in Insolvency Procedure, Sydney, November 1999. 
Svjetska banka, ${ }^{9}$ Međunarodni monetarni fond $(\mathrm{MMF}){ }^{10}$ te UNCITRAL. ${ }^{11}$ Ipak, kako „procesualističko“ stajalište nije jednoznačno, a kako se ne može sasvim zanemariti niti opravdani interes drugih sudionika stečajnog postupka, postoji i druga pravna „struja“ koja zastupa tezu kako stečajni postupak, uz interese vjerovnika, mora zadovoljiti i neke druge, ne manje važne, interese, exempli causa, interese radnika. ${ }^{12}$ Njima se priklonila europska legislativa, ${ }^{13}$ ali i judikatura europskih sudova. ${ }^{14}$

\subsection{Osvrt na noviju hrvatsku stečajnu regulativu: jasni ciljevi, ali bez rezultata}

Analizirajući hrvatsko stečajno pravo u zadnjih 50-ak godina, vidimo da ga karakteriziraju različite etape razvoja. ${ }^{15}$ Kako prijašnji instituti nisu mogli odgovoriti zahtjevima suvremene ekonomije, početkom 90 -ih godina prošlog stoljeća, počelo je približavanje Republike Hrvatske europskom pravnom krugu i njihovim zakonima, ${ }^{16}$ na način da su implementirani stečajni propisi, po uzoru na zemlje Europske unije. ${ }^{17}$ Ipak, stečajna regulativa implementirana 1997. sa svim kasnijim novelama, nije se primjenjivala i neočekivano, stvarni problem nije u prevelikom broju stečajnih postupaka, već činjenica da se na tržištu i dalje nalaze insolventni subjekti nad kojima je odavno trebalo otvoriti stečajni postupak (u teoriji je navedeno poznato kao tzv. anti-commons problem). ${ }^{18}$ To ukazuju i (ne)ostvareni ciljevi - najveći broj stečajnih postupaka zaključuje se zbog nedostatne stečajne mase, $\mathrm{tj}$. bez podjele sredstava vjerovnicima. Glavni je uzrok u tome što se stečajni postupci ne pokreću u zakonom predviđenim rokovima ili se uopće ne pokreću. Daljnji, drugi indikator (ne)uspješnosti stečajnih postupaka jest njegovo vrijeme

9 The World Bank Symposium, Building effective insolvency system-transcript, Washington, D.C., 1999.

10 IMF, Orderly and Effective Insolvency Procedures, Washington, DC, 1999.

11 UNCITRAL, Legislative Guide on Insolvency Law, 2004.

12 Rasmussen, R. K., „An Essay on Optimal Bankruptcy Rules and Social Justice“, University of Illinois Law Review, vol. 1, 1994., str. 1-43.

13 Direktiva 2008/94/EZ Europskog parlamenta i Vijeća od 22. listopada 2008. o zaštiti zaposlenika u slučaju insolventnosti njihovog poslodavca (OJ 283/36, 28. X. 2008.).

14 Podrobnije, Bodul, D., Grbić, S., „Otkaz ugovora o radu u praksi Europskog suda za ljudska prava“, časopis Radno pravo, 2014., br. 9., str. 40-50.

15 Podrobnije, Bodul, D. et al., „Pravnopovijesni i poredbenopravni prikaz razvoja stečajnog postupka“, Zbornik Pravnog fakulteta Sveučilišta u Rijeci, vol. 34, 2013., br. 2, , str. 911-941.

16 Vidi, Barbić, J., „Utjecaj njemačkog prava na stvaranje hrvatskog prava društva“, Zbornik radova Pravnog fakulteta u Splitu, vol. 44, 2007., br. 3-4, str. 339-363.

17 RH je kao zemlja u tranziciji 1997. donijela Stečajni zakon (NN, 44/96) koji je s izmjenama bio na snazi do 2015. kada se implementirao novi Stečajni zakon (NN, 71/15, od 01. rujna 2015.). Međutim, mora se istaknuti kako problematika stečajnog postupka i u zemljama s dugom tržišnom tradicijom predstavlja dinamično područje u kojem se traže nova rješenja koja će pratiti trend promjena.

18 Analize ukazuju kako se na svega $5 \%$ insolventnih pravnih osoba otvara stečajni postupak, a ostalima se tolerira poslovanje u dubokoj insolventnosti, iako je isto kazneno djelo. Za podatke vidi Šverko Grdić, Z., Radolović, J. i Bagarić, L., „Solventnost poduzeća u Republici Hrvatskoj i u Europskoj uniji“, Ekonomski pregled, vol. 60, 2009., no. 5-6, str. 250. et seq. 
trajanja. Ono je dulje od predviđenih rokova i uvjetovano je pravovremenošću pokretanja, načinom zaključenja, neadekvatnim kadrom i kompliciranošću postupka. Konačno, treći su indikator (ne)uspješnosti troškovi stečajnoga postupka. Visoko učešće troškova u ukupno ostvarenim prihodima u stečaju u vezi je s trajanjem postupka, visinama naknada i brojem osoba angažiranih u stečajnom postupku te brojem pratećih parničnih i ovršnih postupaka. ${ }^{19}$ Uvažavajući notornu činjenicu kako je insolvencijsko pravo u svim svojim aspektima zahvaćeno nizom (globalnih) društvenih promjena pa se u takvim okolnostima ono često nekontrolirano razvija i dobiva nepoželjne osobine i smjer, svakako je bitno spomenuti i ,eksperiment" kroz institut predstečajne nagodbe reguliran Zakon o financijskom poslovanju i predstečajnoj nagodbi. ${ }^{20} \mathrm{Cilj}$ je bio, po uzoru na europska zakonodavstva, ${ }^{21}$ prisiliti vjerovnike da u razumnom roku, relativno brzo, donesu ključne odluke o sudbini dužnika. ${ }^{22}$ Ipak, teško je odrediti jesu li ciljevi ispunjeni budući da institucije vlasti (Fina, Upravni sud, Trgovački sud) imaju parcijalne nadležnosti u svezi s predstečajnim postupkom i nije jasno tko je nadležan za postupak u cjelini. Štoviše, velik broj poslovnih subjekata koji je sklopio predstečajnu nagodbu još uvijek se nalazi u razdoblju odobrene odgode početka plaćanja (tzv grace period) ili je u tijeku ispunjavanja obveza na temelju odobrenih predstečajnih nagodbi i vrijeme će pokazati hoće li ispuniti preuzete obveze u cijelosti i nastaviti uredno poslovati. Posljedično, statistika predstavljena Hrvatskom saboru 17. travnja 2015. ne otkriva najvažnije: kako sklopljene predstečajne nagodbe funkcioniraju u praksi, vrlo konkretno ispunjava li dužnik uredno preuzete obveze prema vjerovnicima te je li, ako preuzete obveze ne izvršava, nad njim pokrenut stečajni postupak kao krajnja mjera u kojoj više nema mogućnosti za novi početak. ${ }^{23} \mathrm{U}$ praksi, iako je donošenjem ZFPPN-a 2012. znatno izmijenjen stečajni postupak u Republici Hrvatskoj, u

19 Loc. cit.

20 NN, 108/12, 144/12, 81/13, 112/13, 71/15 i 78/15, dalje: ZFPPN.

21 Bodul, D., et al., „Institut stečajnog plana i predstečajne nagodbe u hrvatskom pravu u kontekstu regionalnog i međunarodnog razvoja“, Podjetje in delo, 2013., br. 4, str. 230. et seq. 4.

22 Konačni prijedlog Zakona o financijskom poslovanju i predstečajnoj nagodbi PZE 138, str. 46, odj.

23 Najveći broj prijava, preko 59 \% svih prijava, zaprimljen je u RC Zagreb (nadležan i u postupcima u kojima ukupan iznos dužnikovih obveza naveden u izvješću o financijskom stanju i poslovanju dužnika prelazi iznos od 10.000.000,00 kuna). Od navedenog broja predmeta, u redovnom postupku predstečajne nagodbe zaprimljena je 1.501 prijava, a za skraćeni postupak (ukupan iznos obveza naveden u financijskim izvješćima ne prelazi 2.000.000,00 kuna i dužnik zapošljava manje od 30 radnika) 4.323 prijava. Krajem 2013. riješeno je oko $83 \%$ svih zaprimljenih predmeta, dok ih je $17 \%$ još u radu. Od navedenog broja predmeta, njih 594 završeno je sklapanjem nagodbe pred nadležnim trgovačkim sudom, dok je za 2.815 predmeta podnesen prijedlog za pokretanje stečajnog postupka. Drugim riječima, broj pokrenutih stečajnih postupaka peterostruko je veći od broja predmeta u kojima je pred nadležnim sudom zaključena predstečajna nagodba. Izvješće također ističe kako je vođenje postupaka Fini donijelo nove prihode u iznosu od oko 13,5 milijuna kuna s tim da je od tog iznosa naplaćeno 6,5 milijuna kuna (48 \%). Dakle, više od 50 \% očekivanih prihoda od administrativnih troškova pokretanja i vođenja postupka iz čl. 86. ZFPPN-a i Pravilnika o troškovima postupka predstečajne nagodbe (NN, 5/13. i 23/13.) ostalo je nenaplaćeno i moguće ih je jedino prijaviti kao tražbinu protiv dužnika u stečajnom postupku. Zapravo, ovaj podatak samo potvrđuje našu tezu da je obvezan postupak predstečajne nagodbe za većinu dužnika bio besplatan način predlaganja otvaranja stečajnog postupka. Podrobnije, Učinci predstečajnih nagodbi - Izvješće Fine prezentirano Hrvatskom saboru 17. travnja 2015. 
njegovoj višegodišnjoj praktičnoj primjeni uočeno je niz problema u tumačenju i učincima pojedinih odredbi i instituta, ${ }^{24}$ što će se pokušati otkloniti novim Stečajnim zakonom ${ }^{25}$ i pratećim propisima. ${ }^{26}$

\subsubsection{Počela novog hrvatskog insolvencijskog zakonodavstva: što se normativno} promijenilo odnosno je li problem u samom zakonu ili u njegovu provođenju?

Iako domet novog stečajnog zakona još uvijek nije moguće procijeniti, bitne novine u odnosu na prijašnje stečajno zakonodavstvo ogledaju se i u proširenju predmeta (čl. 1.) te cilja stečajnog postupka (čl. 2.), osobi predstečajnog i stečajnog dužnika (čl. 3.) te reformiranju stečajnih razloga (čl. 5.). U pogledu cilja, zakonodavac određuje mogućnost pokretanja predstečajnog postupka (dalje: PP) prije i izvan pokretanja stečajnog postupka ako postoji predstečajni razlog (prijeteća nesposobnost za plaćanje) (čl. 4.). To je rezultat ideje po kojoj će odredbe o predstečajnoj nagodbi, koje su bile često kritizirane u javnosti i stručnim krugovima zbog pogodovanja dužnicima i zapostavljenosti sudova, biti regulirane novim SZ-om. Naime, u Glavi II SZ-a (čl. 21.-74.) odredbe su o predstečajnoj nagodbi koje su iz ZFPPN-a prešle u SZ kao predstečajni postupak. Tijela PP-a su sudac pojedinac i povjerenik (čl. 21.), a Fina je tehnički i administrativni servis suda (čl. 44.). Pritisak za ovakve reforme, odnosno za jaču ulogu suda u predstečajnim nagodbama, provodila je i primjena čl. 6. iz Europske konvencije za zaštitu ljudskih prava i temeljnih sloboda. ${ }^{27}$ Naime, praksa Europskog suda za ljudska prava naznačuje kako se čl. 6., st. 1. primjenjuje na stečajni postupak ${ }^{28}$ pa prva dvojba koja se odnosi na samu legitimnost procesa dejudicijalizacije kroz model predstečajne nagodbe jest činjenica da stečajnopravna zaštita mora biti u nadležnosti onog tijela koje Konvencija označava nazivom „tribunal“ (bez obzira na to kojoj vlasti pripada), a danas ta svojstva u pozitivnom pravu ima samo sud. ${ }^{29}$ To je rezultiralo „,brisanjem“ zakonodavnih rješenja po kojima je Fina de facto i de jure odlučivala u postupcima predstečajne nagodbe. Novo rješenje ukazuje na samostalnost suda što podrazumijeva da je sud posebna vrsta tijela državne vlasti za koji vrijede posebna pravila organiziranja. U pogledu stečajnih razloga, treba istaknuti da se razlog nelikvidnosti i prijeteće insolventnosti briše, tako da u smislu SZ-a kao stečajni razlozi ostaje nesposobnost za plaćanje

24 Barbić, J. (ur.), Hrvatsko insolvencijsko pravo, Hrvatska akademija znanosti i umjetnosti (HAZU) - Znanstveno vijeće za državnu upravu, pravosuđe i vladavinu prava, Zagreb, 2014.

25 NN, 71/15, dalje: SZ.

26 Zakon o osiguranju potraživanja radnika u slučaju stečaja poslodavca, NN, 86/08, 80/13 i 82/15 stupa na snagu 1. rujna 2015., dalje: ZORP; Zakon o stečaju potrošača, NN, 100/15 stupa na snagu 01. siječnja 2016., dalje: ZSP te Uredba o kriterijima i načinu obračuna i plaćanja nagrade stečajnim upraviteljima (NN, 105/15.), dalje: Uredba 2015.

27 NN-MU, 18/97, 6/99, 14/02, 13/03, 9/05, 1/06 i 2/10, dalje: Konvencija.

28 Arg., S.p.r.l. ANCA and Others protiv Belgije, odluka, 10. prosinca 1984., Decisions and Reports 40, Interfina and Christian della Faille d'Huysse protiv Belgije, odluka, 4. svibnja 1987., br. 11101/84.

29 U predmetu Stran Greek Refineries i Stratis Andreadis protiv Grčke, presuda, 9. prosinca 1994., Serija A, br. 301-B naglasio je važnost vladavine prava s aspekta nedopuštenog utjecaja zakonodavca na ishode sudskih postupaka. 
(insolventnost) i prezaduženost (insuficientnost) (čl. 5.). Prijeteća nesposobnost za plaćanje isključivo je predstečajni razlog i ona postoji ako sud stekne uvjerenje da dužnik svoje postojeće obveze neće moći ispuniti po dospjeću (čl. 4., st .1.). Također je reformiran i sustav dostave (čl. 12.). Sudska pismena dostavljaju se objavom pismena na mrežnoj stranici $e$-oglasna ploča sudova, naravno ako Zakonom nije drukčije određeno. Dostava se smatra obavljenom istekom osmoga dana od dana objave pismena na mrežnoj stranici $e$-oglasna ploča sudova (čl. 12., st. 1.). Novelirana je i obveza osiguranja stečajnog upravitelja od odgovornosti za štetu. Novim se rješenjem traži obvezno osiguranje od odgovornosti prema odredbama koje se primjenjuju na odvjetnike, dakle, troškovi osiguranja ne bi teretili stečajnu masu već stečajnog upravitelja osobno (čl. 81., st. 1., t. 4.). Također je, radi iznimne složenosti dužnosti i faktičnih poslova koje moraju obavljati stečajni upravitelji, zakonodavac reformirao opće (in abstracto) i posebne (in concreto) uvjete za izbor upravitelja (čl. 77.-95.). Dvije važnije novine su i pravo osporavanja tražbina vjerovnika u PP-u i unovčenje predmeta na kojima postoji razlučno pravo u stečajnom postupku. Uz dužnika, pravo osporavanja ima povjerenik (čl. 24.), kao i vjerovnici (čl. 42.), dok se nekretnina na kojoj postoji razlučno pravo prodaje isključivo u stečajnom, a ne u ovršnom postupku, na prijedlog stečajnog upravitelja ili razlučnog vjerovnika, uz odgovarajuću primjenu pravila ovršnoga postupka o ovrsi na nekretninama (čl. 247. st. 1.). ${ }^{30}$ Svakako treba spomenuti još neke novine. Naime, problem je izazivala činjenica da stečajni upravitelj zastupa stečajnu masu i po okončanju stečajnog postupka (čl. 89., st. 1., t. 13.) pa je radi kvalitetnog obavljanja navedene zadaće novost mogućnost upisa stečajne mase u sudski registar radi dobivanja osobnog identifikacijskog broja (OIB-a) i radi kvalitetnije mogućnosti unovčavanja stečajne mase nakon zaključenja stečajnog postupka (Glava XIV., čl. 438.). Daljnja novina jest i mogućnost otvaranja stečajnog postupka nad imovinom pravne osobe koja je prestala postojati. Ova mogućnost proizlazi iz Zakona o sudskom registru ${ }^{31}$ (čl. 70.), a pretpostavka je da likvidator u postupku likvidacije nad imovinom pravne osobe koja je brisana iz sudskog registra na temelju prijavljenih tražbina utvrdi da imovina nije dostatna za namirenje svih tražbina vjerovnika s kamatama (Glava XIII., čl. 437.). Konačno, novost su i stečajni postupci povezanih društava (Glava X., čl. 391.) te reformirani skraćeni stečajni postupak (čl. 428.-436.) i međunarodni stečaj (Glava XI., čl. 392.-427.) koji je sada usklađen s Uredbom 1346/2000. Ipak, kako je predmetna Uredba po pravnoj snazi iznad SZ-a, već je bila u primjeni od 1. srpnja 2013. Nadalje, ponovnim uvođenjem mnogobrojnih opcija u svezi sa stečajnim planom, zakonodavac je priznao propust iz 2012. koji je doktrina (Dika, M., Barbić, J., Eraković A. i Garašić, J.) već ocijenila kao „značajan korak unazad u razvoju hrvatskog stečajnog prava, a posebice instituta stečajnog plana“". ${ }^{32}$ Naime,

30 Vidi Čuveljak, J., „Neprimjenjivost Pravilnika o ovršnoj prodaji nekretnina kod prodaje u stečajnom postupku“, Pravo u gospodarstvu, vol. 3, 2015., br. 54, str. 375. et seq.

31 NN, 1/95, 57/96, 1/98, 30/99, 45/99, 54/05, 40/07, 91/10, 90/11, 148/13 i 93/14.

32 Opširnije, Garašić, J., „Stečajni plan nakon izmjena i dopuna Stečajnog zakona 2012.“, u: Djelotvorna pravna zaštita u pravičnom postupku - Izazovi pravosudnih transformacija na jugu Europe, Liber amicorum Mihajlo Dika, Zbornik radova u čast 70. rođendana prof. dr. sc. M. Dike (ur. A. Uzelac, J. Garašić, A. Maganić), Pravni Fakultet, Zagreb, 2013., str. 490. et seq. 
za proeuropski je krug karakteristično da je, osim tradicionalnog modela stečaja s prodajom pojedinačnih sredstava ili poduzeća u cjelini, u posljednja tri desetljeća, po uzoru na glavu 11. Stečajnog zakonika SAD-a, razvijen i model reorganizacije dužnika koji za cilj ima vjerovnicima osigurati vrijednost koja je kvantitativno najmanje jednaka onome što bi primili tijekom stečajnog postupka koji kao krajnji rezultat ima likvidaciju, dakle brisanje dužnika. Stoga, nakon desetljeća praktične i normativne marginaliziranosti ciljeva stečajnog postupka, a posebno posljednjih nekoliko godina, tendencija nužnosti opstanka subjekta kroz, prvo preustroj, pa stečajni plan, pa kroz institut predstečajne nagodbe, sada kroz predstečajni postupak i nova-stara rješenja stečajnog plana, postala je sam vrh liste pravno-političkih ciljeva reforme trgovačkog pravosuđenja. Međutim, indikativna metoda utvrđivanja činjenica ukazuje kako je struktura dugoročno blokiranih trgovačkih društava (čiji su računi blokirani više godina) takva da u njima dominiraju ona bez prihoda odnosno ona koja u svojim bilancama ne prikazuju postojanje značajne imovine pa je upitno prema kome je ova zakonodavna tendencija usmjerena.

Ipak na postulatima financijskog oporavka implementiran je i spomenuti ZSP. Naime, u reorganizaciji trgovačkog društva, kao vidu alternative stečaju, primjećujemo određene sličnosti s institutom stečaja nad imovinom potrošača (čl. 4.) s obzirom na to da je ,ekonomsko ozdravljenje“ potrošača kao subjekta postupka upravo i primarni cilj (čl. 2.).

Svakako treba spomenuti kako je zakonodavac u želji i daljnjeg ekonomskosocijalnog poboljšanja položaja radnika, ali i radi usklađivanja s odredbama SZ-a i Zakona o radu, ${ }^{33}$ po hitnom postupku i drugi put novelirao Zakon o osiguranju potraživanja radnika u slučaju stečaja poslodavca (vidi infra t. 2.1.1.1.2. i 2.1.1.1.2.1.). Uz već postojeći sustav zaštite materijalnih prava radnika u slučaju stečaja poslodavca radi zaštite materijalnih prava radnika proisteklih iz radnog odnosa, najnovijim izmjenama i dopunama, na novi način štiti se i egzistencija radnika isplatom minimalne plaće od strane Agencije u slučaju blokade računa poslodavca zbog nemogućnosti prisilne naplate neisplate plaće odnosno naknade place (Glava IIA., čl. 4c, 4d i 4e.).

U konačnici, kako je 2015. u potpunosti redefinirano hrvatsko insolvencijsko pravo, a radi redefiniranja ovlaštenja i odgovornosti stečajnog upravitelja bilo je, prema shvaćanju zakonodavca, nužno i nomotehnički urediti pitanje nagrade operativnih tijela stečajnog postupka, stečajnog upravitelja, kroz novu Uredbu 2015.

Iako novi propisi sadrže velik broj novih instituta i mehanizama, može se reći da nije došlo do radikalnih konceptualnih izmjena, tako da posljedično ne bi trebalo doći do većih problema u primjeni. U stručnoj javnosti mogu se, pa i opravdano, čuti i mišljenja da su i ovi propisi u pojedinim segmentima nedorečeni i neprecizni, međutim oni svakako predstavljaju moderno uređen stečajni okvir. Suma summarum, cilj našeg stečajnog postupka, barem normativno, i zadnjim novelama je, ostao nepromijenjen tijekom zadnjih desetljeća, uz iznimku redefiniranja pasivne stečajne sposobnosti odnosno kruga osoba dužnika protiv kojih se stečajni postupak može

33 NN, 93/14. na snazi od 07. kolovoza 2014., dalje: ZOR. 
provesti. Dakle, stečajni postupak se prvenstveno provodi radi skupnog namirenja vjerovnika stečajnog dužnika, unovčenjem njegove imovine i podjelom prikupljenih sredstava vjerovnicima, a može se provesti i stečajni plan radi uređivanja pravnog položaja dužnika i njegova odnosa prema vjerovnicima, a osobito radi održavanja njegove djelatnosti (čl. 2., st. 2. i 3. SZ). Cilj predstečajnog postupka je u osnovi reorganizirati one subjekte koji su u suštini financijski ,zdravi“ i imaju poslovnu perspektivu, ali im je glavna prepreka za dalji napredak nepovoljan odnos u bilanci (čl. 2., st. 1. SZ-a). Postupak stečaja potrošača ima specifičan materijalnopravni cilj koji se odnosi samo na ,rehabilitaciju“ dužnika što predstavlja differentia specifica u odnosu na korporativni stečaj (čl. 2. ZSP-a).

\subsubsection{Tijela i sudionici stečajnog postupka i mogućnosti usklađivanja njihovih interesa}

Ono što niti u ovoj zakonodavnoj reformi nije napravljeno, a što odudara od aktualnih zahtjeva nomotehničke politike, uvodno je definiranje pojmova koje nije obvezno, ali je u navedenom slučaju preporučljivo. ${ }^{34}$ Naime, mišljenja smo kako je navedeno potrebno radi stjecanja uvida kako se cilj stečajnog postupka ostvaruje prema svakom od sudionika postupka. Štoviše, ovisno o sudionikovu statusu te položaju utvrđenog u stečajnom postupku, ovisit će i način definiranja cilja svakoga od navedenih sudionika postupka. Stoga pokušat ćemo navesti i definirati neke od pojmova, u širem smislu, koji su vezani za osobe i tijela koji izravno ili neizravno sudjeluju u stečajnom postupku.

\subsection{Državni i lokalni interesi u stečajnom postupku: između tržišta laissez faire $i$ ad hoc intervencionizma}

Pokušaj empirijskog i pravno-literarnog definiranja pojma, uloge i obveza države u (bilo kojem) postupku nužno nameću potrebu sagledavanja različitih pogleda na demokratsko-konstitucionalni karakter i ulogu države, a zatim i na analizu nekih aspekata pravnog i ekonomskog funkcioniranja čime bi rasprava daleko nadišla okvire rada. Stoga u mnoštvu odrednica države in extenso ograničit ćemo se na položaj države u građanskom parničnom postupku i na razlikovanje dviju situacija. Prva je situacija kada država postupa kao komercijalna osoba, prema propisima civilnog prava (iure gestionis), a druga je situacija kada država nastupa autoritativno kao javnopravna vlast (iure imperii). U prvom je slučaju država potpuno ravnopravna (koordinirana) s drugim subjektima, dok se u drugom slučaju radi o odnosu tijela javne vlasti i pojedinca koji je njoj podređen (subordiniran). Tu država, djelujući izravno kroz sudove, a neizravno kroz zakonodavnu aktivnost, čuva ili barem nastoji očuvati opći interes te stabilnost pravnog i ekonomskog sistema. Zbog toga pravne subjekte koji nisu sposobni uredno ispunjavati svoje dospjele dugove treba

34 Vidi: Jedinstvena metodološko-nomotehnička pravila za izradu akata koje donosi Hrvatski Sabor, NN, 74/15, čl. 4., st. 2 . 
ili likvidirati ili reorganizirati. U navedenom kontekstu posebno je važno i pitanje pravnog položaja države kao stečajnog vjerovnika.

SZ određuje da država kada nastupa kao komercijalni vjerovnik spada u drugi viši isplatni red (čl. 138., st. 2.). U teoriji je zastupljeno stajalište da stečajni propisi koji daju prioritet državi kao komercijalnom vjerovniku u odnosu na ostale komercijalne vjerovnike, predstavlja nedozvoljeni različiti pravni tretman vjerovnika iste kategorije.

S druge strane, sasvim je drugačiji procesni položaj države onda kad nastupa kao javnopravni vjerovnik. Tu se država može naći u statusu izlučnog vjerovnika ako se neka stvar u državnom vlasništvu zatekne kod dužnika u trenutku otvaranja stečajnog postupka. Tada državni odvjetnik kao zastupnik države sui generis može kao izlučni vjerovnik tražiti: izlučenje predmeta koji je državno vlasništvo, protučinidbu ako je predmet otuđen, a protučinidba je moguća, naknadu pretrpljene štete kao vjerovnik stečajne mase ako je predmet otuđen od strane privremenog ili stečajnog upravitelja, a nije moguća protučinidba iz stečajne mase, te naknadu štete kao stečajni vjerovnik ako je predmet otuđen prije stečaja. Izlučni vjerovnik nije stečajni vjerovnik, pa se državni odvjetnik sa zahtjevom obraća stečajnom upravitelju za povrat stvari. Ako stečajni upravitelj odbije vratiti stvar, pokreće se parnica pred nadležnim sudom za povrat stvari. Dakle, u ovom slučaju državni odvjetnik kao zastupnik države sui generis pravo na povrat stvari ostvaruje izvan stečaja. U slučaju da je stvar otuđena prije ili za vrijeme stečajnog postupka, pravo na naknadu štete ostvaruje se u stečajnom postupku, a pri tomu državni odvjetnik kao zastupnik države sui generis nastupa kao vjerovnik stečajne mase ili stečajni vjerovnik (čl. 147., 148. i 258., st. 1. SZ-a). Država, djelujući s pozicije iure imperii, privilegira određena potraživanja, konkretno potraživanja radnika u bruto iznos, dakle gdje osim neto primitka radnika ulazi i pripadajući porez, odnosno prirez, obvezni doprinosi za mirovinsko i zdravstveno osiguranje kako proizlazi iz ugovora o radu, pravilnika o radu odnosno iz kolektivnih ugovora. To je svakako i rezultat posljedica koje otvaranje stečajnog postupka ima na socijalne prilike u hrvatskom društvu, a koje zasigurno nisu zanemarive. ${ }^{35}$ Dakle, dio dospjelih potraživanja radnika u vrijeme otvaranja stečajnog postupka smatra se troškovima stečajnog postupka (dio koji ne ostvaruje prema posebnom propisu) (čl. 155., st. 2. SZ-a) i namiruje se u cijelosti, u pravilu odmah po priljevu gotovinskih sredstava, dok se ostali dio njihove tražbine u bruto iznosu nastale do dana otvaranja stečajnog postupka smatra tražbinom prvog višeg isplatnog reda (čl. 138., st. 1. SZ-a). U nekim drugim slučajevima kada se radi o predmetima za koje postoji obveza plaćanja carine ili poreza koji služe osiguranju javnih davanja, država ima položaj (privilegiranog) razlučnog vjerovnika (čl. 152., st. 4. SZ-a) ${ }^{36}$ Kada je država stekla status razlučnog vjerovnika ima se pravo namiriti

35 Bodul, D., et al., „O načelu socijalnog postupanja u stečajnom postupku s naglaskom na prava radnika“, Zbornik Pravnog fakulteta Sveučilišta u Rijeci, vol. 34, 2013., no. 1, str. 525-560.

36 Vrlo opsežan Zakon o kreditnim institucijama (NN, 159/13, 19/15 i 102/15, dalje: ZKI) (sadrži 390 članaka) tematiku stečaja nad kreditnim institucijama uređuje, kao lex specialis u samo nekoliko odredbi (čl. 264.-276.), dok se za sve ostalo što nije propisano tim Zakonom primjenjuju pravila SZ-a (čl. 264. ZKI-ja). Jedno od pitanja koje ZKI samostalno regulira jesu i tražbine stečajnih vjerovnika viših isplatnih 
iz svog razlučnog prava, ali je dužna obavijestiti stečajnog upravitelja o svom razlučnom pravu, pravnoj osnovi razlučnog prava i dijelu imovine stečajnog dužnika na koji se odnosi razlučno pravo (čl. 258., st. 2. i 3. SZ-a). Takvo se rješenje može braniti s teorijskog aspekta, s obzirom na to da se javnopravni odnosi u području poreza i drugih javnih davanja (primjerice, doprinosi, pristojbe, carine i dr.), između države, s jedne, te fizičkih i pravnih osoba, s druge strane, uvijek zasnivaju u općem interesu, tj. imajući u vidu potrebu financiranja javnih usluga. ${ }^{37}$ Ipak, postoje autori koji navode kako je za raspravu i pitanje opravdanosti privilegiranog tretmana države kao javnopravne vlasti odnosno javnopravnog vjerovnika (u pogledu poreza i carina) u odnosu na obične vjerovnike s neosiguranim tražbinama. Exempli causa, u skandinavskim stečajnim propisima položaj države kao javnopravne vlasti ni po čemu se ne razlikuje od položaja ostalih vjerovnika jer se smatra kako nije pravedno da se država razlikuje od ostalih vjerovnika te da sebe stavlja u bolji položaj samo zato jer donosi propise koji obvezuju sve sudionike tržišta. ${ }^{38}$ Analizirajući noviju hrvatsku stečajnu regulativu, vidimo kako je država ograničena pravilima europske pravne stečevine odnosno pravilima o državnim potporama kojima je cilj omogućiti jednakost djelovanja poduzetnika na tržištu odnosno onemogućiti nacionalnom tijelu javne vlasti selektivno dodjeljivanje prednosti nekom poduzetniku. Štoviše, dosadašnja iskustva predstečajnih nagodbi iz Zakona o financijskom poslovanju i predstečajnoj nagodbi ${ }^{39}$ ukazuju na opreznost s obzirom na to da su modusi oprosta

redova (čl. 274.). Uočili smo, nadalje, i vrlo povoljan položaj Državne agencije za osiguranje štednih uloga i sanaciju banaka (dalje: DAB) u stečajnom postupku koji se s pravom može problematizirati jer njegov, u suštini privilegirani, status (treći viši isplatni red) jamči namirenje u cijelosti s obzirom na to da su potraživanja radnika stečajnog dužnika (prvi viši isplatni red) i potraživanja HNB-a (drugi viši isplatni red) zajedno s troškovima stečajnog postupka u stečaju nad kreditnim institucijama gotovo zanemariva u odnosu na sveukupnu stečajnu masu. Šire gledajući, DAB u stečajnim postupcima zapravo profitira: najprije godinama (počevši od osnivanja kreditne institucije) stječe prihode iz premija osiguranja depozita naplaćene od kreditnih institucija (Zakon o osiguranju depozita (NN, 82/15, dalje: ZOD, čl. 9.), zatim u nastupu osiguranog slučaja isplaćuje obeštećenje građanima, malim poduzetnicima i neprofitnim institucijama, tj. vjerovnicima (čl. 5. ZOD-a) koje na kraju potpuno regresira iz stečajne mase (čl. 5. ZOD-a). Možda bi trebalo razmisliti o tome da sustav osiguranja depozita obuhvati odgovornost DAB-a, odnosno Republike Hrvatske, do punog iznosa depozita umjesto sadašnjeg iznosa do 100.000,00 eura. Vidi, Bodul, D., et al., „Stečaj nad kreditnim institucijama, isplatni redovi i mogućnost reorganizacije“, Pravo i porezi, 2013., br. 5, str. 13-15.

37 Prof. Jelčić tako ističe kako je jedno od temeljnih obilježja svih javnih prihoda njihova funkcija podmirenja javnih potreba. Podrobnije, Jelčić, B., Financijsko pravo i financijska znanost, Narodne novine, Zagreb, 2008., str. 50. et seq.

38 Tako i detaljnije Radović, V., „Stečajni isplatni redovi“, Pravni život, vol. 54, 2005., str. 87-106.

39 NN, 108/12, 144/12, 81/13, 112/13, (71/15 i 78/15) (dalje: ZFPPN). Na temelju čl. 211.a Općeg poreznog zakona (NN, 147/08, 18/11, 78/12 i 136/12) Vlada Republike Hrvatske donijela je Uredbu o uvjetima, načinu i postupku raspolaganja tražbinama s naslova poreznog duga u postupku predstečajne nagodbe (NN, 3/13.). Ova Uredba sadrži opće odredbe za redovni i skraćeni postupak predstečajne nagodbe, ali i različita pravila u postupku odlučivanja poreznih tijela u svezi s podnesenim zahtjevima (prijedlozima) dužnika. U meritumu, u skraćenom postupku predstečajne nagodbe (dužnik čiji ukupan iznos obveza naveden $u$ izvješću o financijskom stanju i poslovanju dužnika ne prelazi iznos od 2.000.000,00 kuna i koji zapošljava manje od 30 radnika) u postupku obrade urednog zahtjeva dužnika putem obrasca ZSS-a, savjetodavno vijeće poreznog tijela, prilikom davanja prijedloga posebno uzima u obzir održivost plana financijskog restrukturiranja dužnika, vrstu djelatnosti i broj zaposlenih, kontinuitet plaćanja poreznih obveza, te eventualno poduzete pravne radnje dužnika na štetu vjerovnika. S druge strane, u postupku odlučivanja o pravima iz porezno-dužničkog odnosa u redovnom postupku predstečajne nagodbe (dužnik koji nije obuhvaćen pretpostavkama - uvjetima za skraćeni postupak predstečajne nagodbe), savjetodavno 
poreznog duga kao instrumenti dodjele državnih potpora dio iznimno detaljnog i složenog sustava pravila o državnim potporama. Stoga, budući da se i Porezna uprava RH, kada je porezni dug u pitanju, javlja kao vjerovnik u insolvencijskim postupcima, otvorila su se brojna pitanja na koja nije bilo jasnih odgovora, pa je pitanje pravnog položaja države u takvim postupcima trebalo urediti posebnim aktom - Uredbom o uvjetima, načinu i postupku raspolaganja tražbinama s naslova poreznog duga u predstečajnom i stečajnom postupku ${ }^{40}$ - kako bi se izbjegla svaka arbitrarnost u postupanju državnih tijela.

$\mathrm{Na}$ kraju ne treba zaboraviti ni interes lokalnih jedinica, kao subjekta prava, odnosno njihov interes za spašavanje velikih lokalnih subjekata koji predstavljaju strateški interes te nerijetko značajan izvor zaposlenosti i prihoda. U pogledu prve situacije pozitivna stečajna regulativa, za sada, isključuje mogućnost provođenja stečaja nad imovinom jedinica lokalne samouprave (čl. 3., st., 2., t. 4. SZ-a), štoviše, mogli bismo reći da nikakva ex post pravna rješenja ne postoje u slučaju da lokalna

vijeće poreznog tijela pri davanju prijedloga posebno uzima u obzir također održivost plana financijskog restrukturiranja dužnika, vrstu djelatnosti i broj zaposlenih, kontinuitet plaćanja poreznih obveza, te eventualno poduzete pravne radnje dužnika na štetu vjerovnika. U postupku prije podnošenja prijedloga za otvaranje postupka predstečajne nagodbe pred FINA-om, nadležno savjetodavno vijeće može pregovarati s dužnikom o mogućnostima i mjerama iz plana financijskog restrukturiranja predviđenih ZFPPN-om s naglaskom na očuvanje broja zaposlenih i radnih mjesta. Ukratko: u redovnom i skraćenom postupku predstečajne nagodbe, kao i u postupcima pregovaranja prije podnošenja prijedloga za otvaranje postupka predstečajne nagodbe pred FINA-om, dužnik kroz plan restrukturiranja mora uvjeriti porezna tijela $u$ svoju održivost na tržišnim kriterijima. Alternativa je stečajni postupak, ako postoje stečajni razlozi. Dakle, u slučaju neplaćanja poreznih obveza, a u kontekstu insolvencijskog zakonodavstva, država pravne subjekte koji nisu sposobni uredno ispunjavati svoje dospjele dugove „upućuje“ ili na postupak stečajne likvidacije ili na reorganiziranje (predstečajni ili stečajni postupak), primjenjujući pritom metode reprograma ili otpisa dijela ili cijelog poreznog duga. Vidi Janeš, Z., ,Državne potpore i predstečajna nagodba“, Računovodstvo i financije, 2012., br. 12, str. 46. et seq. U pogledu predstečajnih nagodbi, nismo našli niti jedan primjer gdje se država pri otpisu ili reprogramiranju poreznog duga u predstečajnim nagodbama odnosno pri pretvaranju svojih potraživanja u temeljni kapital dužnika, ponašala na način da je nezakonito dodijelila državne potpore. Ipak, valja biti svjestan kako je razdoblje zastare od mogućeg povrata potpore u EU deset godina (Čl. 233., st. 1. Zakona o obveznim odnosima, NN, 35/05, 41/08, 125/11 i 78/15). U navedenom članku ZOO-a propisano je da sve tražbine, utvrđene pravomoćnom sudskom odlukom ili odlukom drugog nadležnog tijela javne vlasti, ili nagodbom pred sudom ili drugim ovlaštenim tijelom, odnosno javnobilježničkim aktom, zastarijevaju za deset godina, pa i one za koje zakon inače predviđa kraći rok zastare. Razdoblje počinje teći od dana dodjele potpore, uz napomenu da svakom radnjom odnosno zahtjevom Europske komisije pri ocjeni nezakonito dodijeljene potpore zastara od 10 godina određuje se od datuma poduzimanja takve radnje.

$40 \mathrm{NN}, 122 / 15$. Iako je implementacijom instituta predstečajnog postupka institut predstečajnih nagodbi stavljen izvan snage, pitanje poreznog duga je i dalje ostalo osjetljivo. Ipak, u odnosu na prijašnje zakonsko rješenje, zakonodavac izrijekom više ne predviđa dosadašnja ograničenja, tj. pravila o otpisu odnosno postotku ispunjenja tražbina koje dužnik može ponuditi vjerovnicima s obzirom na rokove ispunjenja obveza dospjelih do otvaranja predstečajnog postupka. Međutim, u postupku prije podnošenja prijedloga za otvaranje predstečajnog postupka, nadležno Savjetodavno vijeće može pregovarati s dužnikom o mogućnostima i mjerama iz plana restrukturiranja predviđenih SZ-om. Ipak, ako je planom restrukturiranja predloženo smanjenje tražbine Republike Hrvatske, nadležno državno odvjetništvo dužno je zatražiti prethodnu suglasnost ministra nadležnog za financije, odnosno čelnika državnog tijela iz čijeg djelokruga proizlaze tražbine. O izdavanju prethodne suglasnosti, ministar nadležan za financije, odnosno čelnik državnog tijela iz čijeg djelokruga proizlazi tražbina dužan je odlučiti u roku od osam (8) dana od dana primitka zahtjeva (čl. 54. SZ-a). Naravno, i u ovakvim slučajevima financiranja mora postojati održiv plan restrukturiranja. Kako bi se utvrdilo ili isključilo postojanje državne potpore, provodi se analiza (test) koji se uglavnom odnosi na načelo ,pažljivog privatnog vjerovnika“. 
jedinica postane insolventna (čl. 4., st. 6. Ovršnog zakona) ${ }^{41}$ Za drugu situaciju karakteristično je to da lokalna jedinica kroz utjecaje na državnoj razini pokušava ispuniti svoju očekivanu socijalnu i ekonomsko-političku funkciju spašavanjem infrastrukturnih gubitaša od stečaja, zadržavajući pritom one subjekte koji, barem po njezinu mišljenju, predstavljaju oslonac politike (razvoja) ${ }^{42}$ Iz perspektive drugih sudionika tržišta, to predstavlja pokrivanjem gubitaka pojedinačnog subjekta putem nekog od oblika proračunskog financiranja, dakle klasični intervencionizam. ${ }^{43}$

\subsection{Interesi radnika: konflikt ekonomskih $i$ socijalnih postulata}

Posebno osjetljiva pitanja stečajnog postupka vezana su za status radnika. Promjenama stečajnih propisa u zadnjih dvadesetak godina, zakonodavac je pokušao dati posebnu zaštitu radnika. Radnici su zbog toga mijenjali i status i naslov $i$ isplatni red, a tražbina im se dijelila na tražbinu vjerovnika stečajne mase i tražbinu stečajnih vjerovnika prvog višeg ili drugog višeg isplatnog reda. Normativno, položaj radnika u stečajnom postupku određuju relevantne odredbe SZ-a, prvenstveno čl. 191. kroz posebne odredbe o ugovoru o radu. Također, SZ kao opći stečajni propis radnicima kao vjerovnicima daje ovlaštenje podnijeti prijedlog za otvaranje stečajnog postupka ako učine vjerojatnim postojanje svoje tražbine i kojeg od stečajnih razloga (čl. 109., st. 2.). Naše stečajno pravo dodatno honorira radnika kao predlagatelja stečaja jer ga oslobađa plaćanja troškova stečajnog postupka (čl. 114., st. 3. SZ-a). Pravovremenim pokretanjem stečaja radnik stječe i prava određena lex specialis zakonom, Zakonom o osiguranju potraživanja radnika u slučaju stečaja poslodavaca. U slučaju nepokretanja stečajnog postupka, radnik snosi rizik da će svoja prava teže ostvariti nego u slučaju pravovremenog pokretanja stečaja jer je potencijalna stečajna masa protekom vremena sve manja. Prema Stečajnom zakonu radnik se pojavljuje kao stečajni vjerovnik prvog višeg isplatnog reda za tražbine do dana otvaranja stečajnog postupka (čl. 71.) te kao vjerovnik stečajne mase - trošak stečajnog postupka (čl. 86.) i ostale obveze stečajne mase (čl. 87.). Nadalje, na pravni

41 NN, 112/12, 25/13 i 93/14, dalje: OZ. „Predmet ovrhe ne mogu ... objekti namijenjeni radu jedinica lokalne i područne (regionalne) samouprave i pravosudnih tijela“. Vidi Mihelčić, G., u suradnji s Kontrec, D., Komentar Ovršnog zakona, Organizator, Zagreb, 2015., str. 49. et seq.

42 Primjerice, Vlada je donijela Uredbu kojom Imunološki zavod (IZ), iako su ispunjenje pretpostavke za otvaranje stečajnog postupka, postaje javna ustanova od strateškog i općeg gospodarskog interesa za Republiku Hrvatsku, u cilju osiguravanja opstojnosti proizvodnje cjepiva i krvnih derivata iz ljudske plazme kao proizvodnje od strateške važnosti za zdravstveni sustav Hrvatske i zaštite zdravlja njezinih stanovnika. Vidi, Uredba o osnivanju Imunološkog zavoda, NN, 91/15 od 21. kolovoza 2015.

43 Naime, u situacijama gdje nelikvidnost postaje rasprostranjen problem, kao i u Republici Hrvatskoj, funkcija stečajnog prava mijenja smjer te od problema korporativnog upravljanja postaje problem ekonomske politike. Ipak treba istaknuti kako fenomen državnog intervencionizma nije karakteristika samo ovog podneblja. Primjerice, 2002. uprava privatne kompanije British Energy određuje britanskoj vladi da će prestati s isporučivanjem električne energije ukoliko ne dobije hitnu financijsku pomoć. Vlada je mogla birati između poštovanja tržišnih zakona, što bi značilo prepustiti ovu kompaniju tržišnim sankcijama, tj. stečaju, i samim tim ostavi milijune građana u mraku ili odobriti traženi zajam od milijardu eura. Zajam je odobren. Podrobnije, Bujišić-Petrović, B., „Nacionalna država i Nadnacionalni biznis“, u: Biznis i država, Institut društvenih nauka - Centar za ekonomska istraživanja, Beograd, 2006., str. 281288. 
položaj radnika pored SZ-a bitan utjecaj ima i (novi) ZOR ${ }^{44}$ kao i ZOPR. Povijesno, Zakon o osiguranju potraživanja radnika u slučaju stečaja poslodavca iz $2003 .{ }^{45}$ prvi je hrvatski zakon koji se isključivo bavi materijom zaštite radničkih prava u stečaju. Ovim Zakonom u tu svrhu osnovan je Fond za razvoj i zapošljavanje. Stupanjem na snagu novog Zakona iz 2008., poslove Fonda preuzima Agencija za osiguranje radničkih potraživanja u slučaju stečaja poslodavca kao tijela koje tu zaštitu provodi po pravilima općeg upravnog postupka. Naime, radnici koji imaju potraživanja prema tvrtki u kojoj su radili, a koja se našla u stečaju ili u blokadi, dobivaju mogućnost naplate dijela potraživanja izvan i prije samog stečajnog postupka, a bez obzira na sudbinu stečajne mase. Njihova potraživanja preuzima Agencija za osiguranje radničkih potraživanja u slučaju stečaja poslodavca. Uz već postojeći sustav zaštite materijalnih prava radnika u slučaju stečaja poslodavca radi zaštite materijalnih prava radnika proisteklih iz radnog odnosa, najnovijim izmjenama i dopunama na nov se način štiti i egzistencija radnika isplatom minimalne plaće od strane Agencije u slučaju blokade računa poslodavca zbog nemogućnosti prisilne naplate neisplate plaće odnosno naknade plaće ${ }^{46}$ (Glava IIA., čl. 4c, 4d i 4e. ZOPRa). ${ }^{47}$ Tako definiran novi institut može po obujmu i po važnosti parirati onome koji uređuje osiguranje radnika u slučaju stečaja poslodavca. Ipak, bez obzira na višu razinu zaštite prava radnika opravdano je postaviti pitanje razmjernosti (ili proporcionalnosti) implementacije, s jedne strane, zaštite prava radnika odnosno osiguranja pravnog puta za isplatu naknade neisplaćene plaće odnosno naknade plaće i do tri neisplaćene naknade za bolovanje u visini do iznosa minimalne, zajedno s odgovarajućim postupovnim odredbama, a s druge strane, uvedenog materijalnog i administrativnog troška na teret proračuna i poslodavca. Stoga, iako je rano za reći kakve će učinke navedeno uređenje polučiti, indikativna metoda utvrđivanja činjenica ukazuje na to da navedeno rješenje nema uporište u relevantnim izvorima europskog i međunarodnog prava te da uz skup i kompleksan sustav uvodi dodatne izdatke u proračunu, uz one koji su prije na raspolaganju Agenciji što svakako može biti argument da je takvo uređenje neproporcionalno. Svakako tvrdnja koja ide u prilog ovoj tezi jest ta da nije provedena procjena učinaka propisa ${ }^{48}$ što bi mogla biti smjernica za donošenje propisa ili za poduzimanje nenormativnih aktivnosti i mjera. U praksi, godine neprimjene SZ-a nad ogromnim brojem (i

44 Vidi, Bodul, D., et al., O načelu socijalnog postupanja... cit., str. 525-560.

$45 \mathrm{NN}, 114 / 03$

46 Ipak, razina i opseg zaštićenih materijalnih prava radnika u slučaju stečaja nisu jednaki razini i opsegu zaštićenih materijalnih prava radnika u slučaju blokade računa poslodavca. Zaštićena radnička prava, a time i zahtjevi prema Agenciji značajno su veći kada se nad poslodavcem provodi stečajni postupak. Upravo bi to mogao biti osnovni razlog zbog kojega će radnici favorizirati pokretanje stečajnog umjesto predstečajnog postupka. To dokazuje i to da radnici nisu baš uvjereni u prosperitet poslodavca koji prolazi PP kroz financijsko i operativno restrukturiranje.

47 Iako ZORP to izrijekom ne navodi, blokada računa poslodavca predstavlja indiciju postojanja barem predstečajnog razloga odnosno ukazuje na potrebu otvaranja predstečajnog postupka koji se provodi prije i izvan stečajnog postupka kroz plan restrukturiranja dužnika. Praksa će pokazati postoji li stvarna usklađenost između odredbi Zakona o radu, SZ-a i konačno ZORP-a o ovom pitanju.

48 Obveza sukladno Uredbi o provedbi postupka procjene učinaka propisa (NN, 66/12) i Zakonu o procjeni učinaka propisa $(\mathrm{NN}, 90 / 11)$. 
državnih) poduzeća dovele su do većeg broja (prividno) zaposlenih. Štoviše, na to ukazuju i učestale promjene položaja radnika u stečajnom postupku vezane uz pokušaj osiguravanja socijalnog mira, posebice nakon što je velikom broju radnika prestao radni odnos otvaranjem stečajnog postupka nad njihovim dotadašnjim poslodavcem. Stvarne mogućnosti ZORP-a, pa i zadnje novele, kao drugog stupa našeg insolvencijskog prava tek će ,amortizirati“ snažne udarce insolvencije trgovačkih društava i time se ne nude dugoročna rješenja. Štoviše, dugoročna rješenja ne nudi, po naravi stvari, niti SZ, a izravni cilj PP-a nije spašavanje radnih mjesta, već se ovaj postupak prvenstveno provodi radi uređivanja pravnoga položaja dužnika i njegova odnosa prema vjerovnicima i održavanja njegove djelatnosti (čl. 2. SZ-a). Tek će se vidjeti hoće li rješenja PP-a u svezi s radničkim pravima biti zapreka uspješnom financijskom restrukturiranju u onim slučajevima ako ne postoji, a najčešće ne postoji, način da se svi radnici stave u punu zaposlenost. Zaključno, treba prihvatiti činjenicu kako veći dio hrvatskoga insolvencijskog prava, kao i insolvencijska prava drugih, posebno posttranzicijskih država, nisu sedes materiae gdje se rješava složena struktura radničkih prava. Paradigma svega jest i činjenica kako je osnivač Agencije Republika Hrvatska, a osnivačka prava i obveze ostvaruje Vlada Republike Hrvatske i, što je najvažnije, financira se iz državnog proračuna. Predstavlja li ovakva zakonska konstrukcija dobro rješenje? S jedne strane, za razliku od „,normalne“ tržišne ekonomije, u kojoj potraživanja radnika prema tvrtki u kojoj rade ne mogu biti veća od jednomjesečne bruto zarade, u posttranzicijskoj Hrvatskoj ta potraživanja mogu biti višegodišnja, pa ima smisla, iz socijalnih razloga, pojačati i ubrzati isplatu dijela tih potraživanja. S druge strane, i doktrinarne rasprave ukazuju kako se ne vidi zašto bi porezni obveznici, među kojima svakako ima i siromašnih, financirali isplatu privatnih tražbina privatnih osoba prema privatnim poslovnim subjektima. Jer, proračunsko financiranje dugova u stečaju klasični je primjer ekonomskog intervencionizma.

\subsection{Interesi sindikata: shvaćanje stečajnog postupka kao postupka privatizacije}

Prethodno rečeno ukazuje na još jedan prateći fenomen mjesta i uloge radnika. Naime, u Republici Hrvatskoj izraženo je zanimanje sindikata za sudjelovanje u stečajnim i predstečajnim postupcima i to, kako u nastojanju postizanja povoljnijeg položaja radnika, tako i pri davanju ocjena o tijeku postupka, kao i o cijenama koje se u stečajnom postupku postižu pri prodaji imovine ili subjekta u cjelini. Štoviše, mnogi sindikalisti drže da bi se radnike trebalo pitati i kod kontrole tijeka stečajnog postupka kada bi trebali dati suglasnost na postignutu cijenu unovčene imovine stečajnog dužnika. ${ }^{49} \mathrm{Za}$ sindikate, stečajni postupak je oblik privatizacije, a ne namirenja vjerovnika. ${ }^{50}$ Međutim, važno je primijetiti kako se ovdje ipak

49 Ipak, treba uzeti u obzir da ovlast o načinu i uvjetima unovčenja dužnikove imovine pripada isključivo skupštini vjerovnika (čl. 38.E, st. 1., t. 3. SZ-a).

50 Exempli causa, rezultat utjecaja sindikata jest status quo položaja radnika kroz naplatu prioritetnih tražbina u postupku sklapanja predstečajnih nagodbi (čl. 3., st. 1., t. 13. ZFPPN-a u vezi s čl. 17., st. 2., t. 
radi o različitim postupcima $\mathrm{i}$ to kako iz perspektive prirode samog postupka $\mathrm{i}$ razloga za njegovo pokretanje, tako i iz perspektive nadležnosti za provedbu kao i sudionika postupka. Naime, sindikat kao udruga u koju se udružuju radnici radi zaštite i promicanja svojih prava i interesa naročito je eksponiran u situacijama kada poslodavac redovito ne ispunjava dospjele ugovorne novčane obveze prema svojim članovima (radnicima). Kao izravna posljedica insolventnosti slijedi u hrvatskim prilikama od sindikata organizirani štrajk kao krajnja mjera upozorenja kojim se de facto ništa ne postiže jer dotično poduzeće već odavno ne posluje uredno pa mu stoga prijeti ekonomski „slom“. U takvom stanju stvari sindikat odnosno radnici kao vjerovnici moraju donijeti jednu od odluka: a) pokrenuti ili b) ne pokrenuti stečajni postupak. Samim otvaranjem stečajnog postupka djelatnost sindikata ne prestaje jer naša pozitivna pravna regulativa ne određuje da je otvaranje stečaja razlog za prestanak ili zabranu njegove aktivnosti (argumentum a contrario djelatnost sindikata može trajati od prijedloga za otvaranje stečajnog postupka pa sve do zaključenja stečajnog postupka). Ipak, s praktične točke gledišta djelatnost sindikata odnosno sindikalnog povjerenika u samom stečaju može se podijeliti u dvije faze: 1.) razdoblje od podnošenja prijedloga do otvaranja stečajnog postupka te 2.) razdoblje od otvaranja stečajnog postupka do njegova zaključenja. U prvom razvojnom stupnju djelatnost može biti značajna (posebno kao pritisak na političku vlast) jer radnici imaju pravo tražiti bez ikakvih ograničenja sva svoja prava dok je u drugom stupnju djelatnost reducirana jer otvaranjem stečajnog postupka prestaju prava radnika na odlučivanje, a sporazumi s radničkim vijećem ne obvezuju stečajnog upravitelja (čl. 192. SZ-a). Sindikat, pak, može i nadalje putem pravnog zastupnika u radnim sporovima kod poslodavca, pred sudom, arbitražom ili drugim državnim tijelima zastupati svoje članove kao vjerovnike stečajnog dužnika te sudjelovati u radu odbora vjerovnika i skupštine vjerovnika kao tijela stečajnog postupka donošenjem odgovarajućih odluka iz svoje nadležnosti. ${ }^{51}$ Dakle, važno je shvatiti kako radnici sudjeluju u stečajnom postupku u dva sasvim različita svojstva - kao „upućene osobe," u svojstvu trenutnih ili bivših radnika stečajnog dužnika, i kao vjerovnici, jer potražuju neisplaćene plaće i doprinose te druga prava (čl. 3 . ZORP-a). Osim toga, oni također mogu biti članovi sindikata, koji će zagovarati interese u ime sindikata. Mnogi radnici (i sindikati) prirodno izjednačavaju stečaj s propadanjem i gubitkom posla i shodno tome, češće razmišljaju o unovčavanju, radije nego o reorganizaciji. Zbog toga su često skloni pripisivati dužnikove

1. i 2. ZFPPN-a). Ovo ističemo kao bitno jer anegdotski dokazi ukazuju kako se sve veći broj subjekata našao u blokadi odmah nakon što je okončana predstečajna nagodba i sada se nalaze pred stečajnom likvidacijom. Razlog tomu je činjenica da se za većinu poslovnih subjekata, čiji je plan restrukturiranja odobrilo Ministarstvo financija, kao nepremostiv korak nakon uspješno odrađene predstečajne nagodbe pokazala već prva uplata za prioritetne tražbine. U postupku predstečajne nagodbe odmah nakon prihvaćanja plana dolaze na naplatu prioritetne tražbine među kojima su, primjerice, plaće radnika. Radnici u većini slučajeva odmah nakon predstečajne nagodbe blokiraju račun (vlastite) tvrtke jer im nisu u zakonskom roku isplaćene zaostale plaće. Uprava se tomu ne može suprotstaviti čime daljnji opstanak tvrtke na tržištu postaje vrlo upitan. Vidi, Učinci predstečajnih nagodbi... cit. 2010

51 Rješenje Visokog trgovačkog suda Republike Hrvatske, posl. br. 66. Pž-5577/10-3 od 28. rujna 
poteškoće samom stečajnom postupku, pri čemu na stečaj gledaju kao na „bolest““. 52 U svakom slučaju, neznanje i strah od posljedica stečajnog postupka doprinijet će da se radnici neprijateljski postave prema samom stečajnom postupku. Isto vrijedi i za sindikate i njihove predstavnike, koji, bez obzira na to što možda neće biti tijela postupka, već će imati nezavisan položaj u stečajnom postupku, mogu pomoći da se radnici educiraju i da se sakupe one informacije koje će koristiti stečajnom upravitelju kao glavnom operativnom tijelu i dužnikovim vjerovnicima. U konačnici, možemo zaključiti kako je utjecaj sindikata, koji nije tijelo postupka, nekada odlučujući. To je posebno došlo do izražaja u novijoj povijesti kroz niz velikih stečajnih i predstečajnih postupaka gdje je država pod pritiskom sindikata, kršeći postojeća stečajna pravila, pokušavala ispuniti svoju očekivanu socijalnu i, šire gledano, političku funkciju. U našim okolnostima, kada je u stečajnom postupku moguć isključivo završetak započetih poslova čije je ispunjenje prijeko potrebno da bi se spriječilo nastupanje štete na imovini stečajnog dužnika (čl. 216.-217. SZa) sindikat mora pronaći nove forme utjecaja na tijek stečajnopravne procedure. Prava radnika moguće je ostvariti jedino kroz tijela stečajnog postupka, a članstvo u odboru vjerovnika čini se jedino mogućim i pravno dopustivim sredstvom. Odbor vjerovnika, naime, u stečaju dužnika donosi kontrolne, savjetodavne i obvezujuće odluke koje imaju utjecaj na sve vjerovnike stečajnog dužnika. U slučajevima kada raniji dužnikovi radnici, kao stečajni vjerovnici imaju tražbine prema stečajnom dužniku, predstavnik radnika mora biti član odbora (čl. 96., st. 2. SZ-a), no, član odbora u svim slučajevima može biti i predstavnik radnika koji bi svojim stručnim znanjem mogao pridonijeti njegovu radu (čl. 96., st. 3. SZ-a). Odbor vjerovnika može skupštini vjerovnika, kao tijelu većih ovlasti, predložiti da se prigodom prodaje imovine dužnika kupca dodatno obveže i na preuzimanje radnika dužnika, a odbor može prilikom izrade stečajnog plana svojim stručnim savjetima stečajnom upravitelju predložiti rješenja koja bi obuhvatila i zaštitu interesa ranijih radnika stečajnog dužnika. Ipak, uloga sindikata probitačnija je prije početka insolvencijskih postupaka kada se na političku vlast, kroz tripartitne pregovore (sindikat, vlada, poslodavac) može utjecati predlaganjem što veće zaštite prava radnika putem legislative. Stečaj dužnika, prema hrvatskom, ali i prema drugim zakonodavstvima razvijenog kapitalističkog svijeta nije postupak u kojem inicijativa sindikata donosi naročitu korist radnicima. To je isključivo sudski postupak u koji se izvršna vlast ni u kojem slučaju ne smije miješati.

\subsection{Interesi vjerovnika: neadekvatno iskorištene mogućnosti}

Oni su ključni ,igrači“ u postupku, jer se, u krajnjoj liniji, stečajni postupak i provodi radi njihove zaštite (čl. 2., st. 1. SZ-a). Vjerovnici su prema SZ-u zastupljeni s dva tijela. To su skupština i odbor vjerovnika. Skupštini su dana najšira prava da donosi ključne odluke o samom tijeku i pravcu realizacije stečajnog postupka.

52 U pitanju je, dakle, temeljno nepoznavanje pravnog statusa stečajnog upravitelja pa se stoga u javnosti širi sasvim iskrivljena slika kako je stečajni upravitelj državni službenik zadužen za rasprodaju visokovrijedne imovine stečajnog dužnika. 
Odbor ima uža ovlaštenja i prvenstveno su usmjerena na nadzorno-savjetodavnu ulogu u praćenju tijeka stečajnog postupka radi poduzimanja određenih koraka i pravodobnog signaliziranja u slučaju da se pojave situacije koje nisu u interesu vjerovnika. U skladu s odredbama novog SZ-a, značajno je spomenuti i da sada umjesto suda, odbor odobrava predračun troškova stečajnog postupka. Ipak u okviru stečajnog postupka svaka od četiri kategorije vjerovnika, izlučni (čl. 147.-148. SZa), razlučni (čl. 149.-153. SZ-a), stečajni vjerovnici (čl. 137-139. SZ-a) te vjerovnici stečajne mase (čl. 154.-157. SZ-a) imaju isti interes: zaštitu prava na ostvarenje svojih tražbina. Izlučni vjerovnici imaju najprivilegiraniji položaj: tražbine koje takav vjerovnik ima odnose se na određenu stvar koja ne pripada stečajnom dužniku te se ta stvar kao takva ima ,izlučiti“ iz stečajne mase te mu se predati na njegov zahtjev. Položaj razlučnih vjerovnika drugačiji je od položaja izlučnih vjerovnika, iako je on još uvijek privilegiran u odnosu na onaj koji imaju stečajni vjerovnici. Naime, razlučni vjerovnici jesu vjerovnici koji za svoja potraživanja prema stečajnom dužniku imaju stvarno-pravna osiguranja. Stečajni vjerovnici su osobni vjerovnici dužnika koji u vrijeme otvaranja stečajnoga postupka imaju koju imovinsko-pravnu tražbinu prema njemu. Oni svoje potraživanje prema dužniku mogu namirivati samo u okviru stečajnog postupka, neovisno o vrsti tražbine. Vjerovnici stečajne mase ne prijavljuju svoje tražbine stečajnom upravitelju, već mogu zahtijevati od stečajnog upravitelja da im plati ono što duguje stečajna masa. Oni se namiruju redom kako dospijevaju njihove tražbine. Te tražbine temelje se na troškovima stečajnoga postupka i na ostalim obvezama stečajne mase. Troškovi stečajnoga postupka namiruju se prije ostalih obveza stečajne mase, a nakon njih ostale obveze stečajne mase. Dakle, vidimo da svaka od ovih kategorija ima različit zakonom utvrđen način svoga ostvarenja te pravni položaj s kojeg djeluje. Njihova stajališta i očekivanja ne moraju se obvezno razlikovati, ali je to, s obzirom na različit položaj i posljedice koje mogu trpjeti tijekom stečajnog postupka, vrlo moguće. Interes vjerovnika u stečajnom postupku također se štiti i jednom procesnom pravnom posljedicom otvaranja stečajnog postupka odnosno zabranom raspolaganja upravi/upravnom odboru stečajnom masom, kao i eliminiranjem iz upravljanja insolventnim društvom. Interes vjerovnika dolazi također u prvi plan i kroz ,,imperativnost“" instituta reorganizacije insolventnog društva. Naravno, ne smije se zanemariti, što je bila praksa, ${ }^{53}$ ekonomski postulat reorganizacije odnosno postojanje opravdanih ekonomskih pokazatelja da se vjerovnici mogu povoljnije namiriti negoli u postupku likvidacijskog stečaja. ${ }^{54}$

53 Primjerice, FINA je trebala nakon neuspjele predstečajne nagodbe ex offo pokrenuti stečajni postupak nad dužnikom. Po logici stvari, to bi trebali biti hitni likvidacijski stečajni postupci radi skupnog namirenja vjerovnika stečajnog dužnika, unovčenjem njegove imovine i podjele prikupljenih sredstava vjerovnicima. Međutim, zakonodavac je kroz prijenosni stečajni plan pružio još jednu, dodatnu priliku insolventnom dužniku na financijski oporavak.

54 Treba istaknuti da niti poslovno okružje nije usmjereno prema stečajnim dužnicima već ih stigmatizira, primjerice, Zakon o javnoj nabavi regulira važno društveno i pravno područje, a polazna osnova svih načela javnih nabava jest princip konkurentnosti (natjecanja), s ciljem dobivanja najbolje kvalitete za odgovarajuću cijenu. Pored ovih temeljnih elemenata načela konkurentnosti, zakon utvrđuje slučajeve u kojima postoje ograničenja za pojedine osobe za sudjelovanje u postupcima nabave. U pitanju su osobe nad kojima je, exempli causa, otvoren stečaj, kao i osobe prema kojima je podnesen prijedlog 


\subsection{Položaj (prijašnje) uprave: mora li stečaj biti smrt trgovačkog društva?}

Iako postoji eksplicitna odgovornost za nepravodobno pokretanje stečajnog postupka, kaznenopravna regulativa se u praksi, zbog nejasnih razloga, gotovo uopće ne provodi te ne postoji niti ikakav strah od eventualnog kažnjavanja. Stoviše, nisu rijetke ni situacije da uprava stečajnog dužnika odbija predati ili prikriva dijelove imovine koje ulaze u stečajnu masu opstruirajući djelovanje stečajnog dužnika i stečajnog upravitelja. Čak i ako su izrečene kazne, one se nalaze na granici zakonskog minimuma tako da kaznena politika pokazuje iznadprosječnu blagost. ${ }^{55}$ To je imalo negativne posljedice za gospodarstvo jer su insolventna poduzeća nastavila poslovati i preuzimati obveze koje nisu bila u mogućnosti podmiriti. To je dovelo do širenja nelikvidnosti i insolventnosti na ostala poduzeća u sustavu, što se pokušalo razriješiti ZFPPN-om. ${ }^{56}$

Nadalje, iako pozitivno hrvatsko pravo prilično kvalitetno definira elemente pojma povezanih društava kroz odredbe Zakona o trgovačkim društvima, ${ }^{57}$ mnogo je manji opseg suglasnosti sa ZFPPN-om koji ukazuje na to da su dužnici, nerijetko priznajući nepostojeće, fiktivne tražbine putem izravno ili neizravno povezanih trgovačkih društava, u potpunosti obezvrijedili tražbine, imovinu stvarnih vjerovnika, pravnih i fizičkih osoba te Republike Hrvatske, jer se na strani dužnika i vjerovnika često nalazi „ista“ osoba, koja ima kontrolu nad nekoliko trgovačkih društava, u kojima su osnivači, članovi uprava ili direktori, odnosno putem udjela u društva u vlasništvu drugog društva te u stvarnosti ne postoji odnos dužnik - vjerovnik. Dakle, s obzirom na uvođenje novog modela stečajnog postupka, predstečajne nagodbe, bez istodobnog propisivanja položaja povezanih društava u pravnom sustavu otvorio se prostor za arbitrarnost u primjeni pravnih normi. Shvaćajući taj propust u ZFPPN-u, SZ uvodi novu Glavu X.a: „Stečaj povezanih osoba“..$^{58}$

za otvaranje stečaja. Podrobnije, Bodul, D., et al., „Položaj stečajnog dužnika u postupcima javne nabave - de lege lata rješenja, pogled u europsko i konvencijsko pravo i pravci promjene“, Zbornik Pravnog fakulteta Sveučilišta u Rijeci, vol. 37, 2016., br. 2, str. 791-805.

55 Majstorović, D., „Stečajna kaznena djela“, Hrvatski ljetopis za kazneno pravo i praksu, vol. 14. , 2007., br. 2, str. 643-671. te Simundić, M., „Stečajni postupak u praksi“, Sudačka mreža: http://www. sudacka-mreza.hr/doc/sr/radovi/Mladen Simundic___Stecajni_postupak_u_praksi.pdf (12. X. 2015.).

56 Pravno pravilo prema kojemu rok plaćanja dospijeva 30 dana od primitka računa ili preuzimanja isporuke, ako nije nešto drugo ugovoreno, donedavno je bilo uređeno odredbom čl. 174. Zakona o obveznim odnosima (NN, 35/05 i 41/08.). Međutim, odredbe tog Zakona koje nisu popraćene sankcijama (osim zateznih kamata i pravom na pokretanje prisilne naplate) nisu shvaćene ozbiljno. Zato je i donesen Zakon o rokovima ispunjenja novčanih obveza (NN, 125/11.) kojim je uvedeno novčano sankcioniranje neplaćanja (do $1.000 .000,00 \mathrm{kn}$ ). Isti se taj ZORINO implementirao u novi ZFPPNs istom novčanom kaznom zbog nepoštovanja roka plaćanja?

57 NN, 34/99, 121/99, 52/00, 118/03, 107/07, 146/08, 137/09, 125/11, 152/11, 111/12, 68/13. i 110/15, čl. 473. et seq.

58 Europska Komisija je zbog onemogućavanja zloupotreba i veće pravne sigurnosti krajem 2012. sastavila Prijedlog izmjena Uredbe o insolvencijskim postupcima, kojim je, između ostalog, djelomično uredila i materiju stečaja povezanih društava (European Commission, Proposal for a Regulation of the European Parliament and of the Council amending Council Regulation (EC) 1346/2000 on insolvency proceedings, Strasbourg, 12. XII. 2012., COM (2012.), 012/0360 (COD), 744 final). Iste još nisu stupile na snagu. 
Nadalje, da li zbog nepoznavanja instituta ili zbog straha od potencijalnih zlouporaba, uprava skoro da nije koristila institut „osobne uprave“ (čl. 356.-371. SZ-a). Ukratko, osobna uprava poseban je stečajni postupak koji se odvija po posebnim pravilima pa se opće odredbe SZ-a primjenjuju tek supsidijarno. To znači da nad insolventnim dužnikom (pravnom osobom ili dužnikom pojedincem) mora biti otvoren stečajni postupak da bi se mogao primjenjivati institut osobne uprave. Sud će osobnu upravu odrediti ako su kumulativno ispunjene sljedeće pravne pretpostavke: 1.) ako to dužnik predloži, 2.) ako se s time suglasio vjerovnik koji je predložio otvaranje stečajnog postupka te 3 .) ako se prema okolnostima slučaja može očekivati da određivanje osobne uprave neće dovesti do odugovlačenja postupka ili do kakvog drugačijeg oštećenja prava i interesa vjerovnika. Ipak institut osobne uprave nije zaživio u našoj stečajno-pravnoj proceduri u 19 godina postojanja. S druge strane, američki model putem glave 11. Stečajnog zakonika SAD-a, tzv. debtor in possession prvotno je razvijen u SAD-u i zahvaljujući pozitivnim rezultatima danas predstavlja sastavni dio gotovo svih, kako europskih tako i azijskih, stečajnih zakonodavstava. Međutim, mnogobrojni su razlozi zašto institut osobne uprave u pozitivnom pravu nije zaživio, a jedan od najvažnijih je nepovjerenje vjerovnika da dužnik (,stara“ uprava) sam i nadalje upravlja i raspolaže stečajnom masom pod nadzorom stečajnog povjerenika. Dvojbeno je, nadalje, i postojanje paralelnog sustava vođenja dužnika od strane uprave i stečajnog povjerenika. Šire gledajući, osobna bi uprava imala smisla jedino ako takva uprava ima specijalistička znanja koja će omogućiti sigurnu rehabilitaciju dužnika (reorganizaciju ili restrukturiranje) i njegov nastavak poslovanja te opstanak na tržištu. Osim toga, osobna uprava je institut koji u praksi može koristiti jedino razlučnom vjerovniku, dok „običnim“ stečajnim vjerovnicima producira dodatne troškove jer se iz stečajne mase moraju namirivati troškovi uprave, stečajnog povjerenika i odbora vjerovnika.

\subsection{Interesi stečajnih upravitelja: potreba profesionalizacije službe}

U specifičnoj funkciji stečajnog upravitelja obuhvaćene su ovlasti specifičnog, izvansudskog tijela stečajnog postupka, s jedne strane, te zakonskog zastupnika dužnika i svojevrsnog upravitelja imovinom stečajnog dužnika, a u ime i za račun stečajnih vjerovnika, s druge strane (nešto je drugačija situacija s dužnikom pojedincem). Ipak, iako je on središnje i u operativnom smislu najvažnije tijelo stečajnog postupka, dosadašnje iskustvo ukazalo je na brojne nedostatke, prije svega u načinu imenovanja i razrješenja, ali i kod nadzora nad radom stečajnog upravitelja i preuzimanja radnji od izuzetnog značaja. Niz novih rješenja trebao bi ukloniti nedostatke i stvoriti prostor za adekvatan razvoj profesije. Stoga su pravila o imenovanju stečajnoga upravitelja doživjela brojne promjene, a važnije su da se za stečajnoga upravitelja može imenovati osoba upisana na listi stečajnih upravitelja za područje nadležnog suda.$^{59}$ Ministar pravosuđa će za područje nadležnosti svakog

59 SZ je kao jedan od posebnih preduvjeta za imenovanje propisao da stečajni upravitelj mora biti dostojan javnog povjerenja za obavljanje profesije, a pritom se smatra da nije dostojna osoba protiv koje je pokrenut kazneni postupak za kaznena djela za koje se pokreće postupak ex offo. Pitanje je je li ovakvo 
suda utvrditi listu A stečajnih upravitelja i listu B stečajnih upravitelja, koje se mogu dopunjavati, a jedna osoba može biti na listi za područje jednog ili više sudova. $\mathrm{Na}$ listu A može biti upisana fizička osoba koja ima poslovnu sposobnost, koja ima završen diplomski sveučilišni studij, odnosno završeno visoko obrazovanje s najmanje 300 ETC bodova, koja ima položen stručni ispit za stečajnoga upravitelja te koja je nakon položenog stručnog ispita obavljala stručnu obuku u trajanju od jedne godine i koja je dostojna za obavljanje poslova stečajnoga upravitelja. Na listu B stečajnih upravitelja može biti upisana fizička osoba koja ispunjava gotovo sve pretpostavke za listu A, osim što nema, nakon položenog stručnog ispita, stručnu obuku u trajanju od jedne godine. Izbor stečajnoga upravitelja u stečajnom postupku obavlja se metodom slučajnog odabira s liste A stečajnih upravitelja za područje nadležnog suda, a ako sud smatra da stečajni upravitelj izabran metodom slučajnog odabira ne raspolaže potrebnom stručnošću ili poslovnim iskustvom potrebnim za vođenje stečajnog postupka, za stečajnog upravitelja može izabrati drugu osobu s liste A stečajnih upravitelja za područje nadležnog suda. Ipak analizom položaja stečajnog upravitelja dolazimo do zaključka kako ne postoje kriteriji za profesionalno bavljenje ovom profesijom, kao i da nema tijela, osim tijela u stečajnom postupku, koji bi provodilo stalan nadzor nad njihovim radom. Rješenje je u uspostavljanju komore stečajnih upravitelja (primjerice, kao u Sloveniji Zbornica upraviteljev Slovenije) koja bi bila zadužena za edukaciju stečajnih upravitelja, zastupanje njihovih interesa i sankcioniranje u slučaju djelovanja protiv interesa vjerovnika i dužnika. Primjerice, praksa da stečajni upravitelji daju savjete prije stečaja, ako takva praksa uopće i postoji, jako je skromna. Iskustvo u drugim nadležnostima, međutim, ukazuje na to da je vrlo vjerojatno da će zahtjevi za predstečajnim savjetima, pa i zbog postojanja predstečajnog postupka, ubrzo postati svakodnevnica. Da bi se iskoristile ove mogućnosti, zainteresirane ce stranke trebati predstečajne usluge upućenih i iskusnih stručnjaka, uključujući stečajne upravitelje, stoga bi postojanje Komore i takvo nešto omogućilo i kvalitetnije reguliralo. Stoga smatramo da stečajni upravitelji trebaju biti organizirani, u duhu našeg pravnog sustava, kroz strukovnu organizaciju Komore stečajnih upravitelja na koju bi se prenijela javnopravna ovlaštenja. U konačnici, bez stručnog operativnog tijela nije moguće zamisliti uspjeh bilo kojeg postupka povodom insolventnosti dužnika u nas, ni u svijetu.

Ipak, to nije jedini problem, možda je i veći problem kompenzacija stečajnih upravitelja. U teoriji, sustavi nagrade stečajnim upraviteljima mogu biti regulirani na četiri načina: (1) prepušteni dogovoru vjerovnika i stečajnog upravitelja; (2) propisani tablicom uvažavajući neke dodatne kriterije poput vremena ili složenosti predmeta; (3) zasnovani na obračunu provedenog vremena na slučaju - prema satnici / dnevnici te (4) model koji koristi većina zemalja, a to je kombinacija navedenih

rješenje u skladu s Ustavom RH (NN, 56/90, 135/97, 8/98, 113/00, 124/00, 28/01, 41/01, 55/01, 76/10, $85 / 10$ i $05 / 14$, dalje: Ustav HR) i Konvencijom s obzirom na to da je svatko nedužan i nitko se ne smije smatrati krivim za kazneno djelo dok mu se pravomoćnom sudskom presudom ne utvrdi krivnja (čl. 28. Ustava RH i čl. 6., st. 2. Konvencije). O istom trenutno odlučuje i Ustavni sud RH po prijedlogu za ocjenu ustavnosti, br. U-I-2806/15. 
sustava. Naravno, različiti sustavi obračuna nagrade i naknade imaju svoje prednosti i nedostatke. Ipak u zemljama precedentnog prava nagrada i naknada formiraju se u pregovorima vjerovnika i upravitelja, uz mogućnost korištenja tablica, dok se u zemljama kontinentalnog sustava prava, pa i u Republici Hrvatskoj, prvenstveno koristi metoda propisanih tablica. ${ }^{60}$ Iz perspektive stečajnih upravitelja, nova Uredba 2015 kojom se utvrđuju kriteriji i način obračuna i plaćanja nagrade stečajnim upraviteljima nije na zadovoljavajući način riješila tri bitna praktična pitanja: 1.) precizan rok u kojem sud mora donijeti rješenje o nagradi za rad, 2.) isplatu predujma dijela nagrade tijekom provođenja svakog stečajnog postupka u kojem postoji stečajna masa te 3.) posebnu naknadu za vođenje poslovanja kada stečajni dužnik nastavlja poslovati tijekom stečajnog postupka. U odnosu na rok, Uredba je neprecizna: „Nagradu za obavljene poslove određuje sud bez odgode prema pravilima ove Uredbe, nakon što osobe iz stavka 1. ovoga članka dovrše sve poslove za koje su imenovani“" (st. 2., čl. 2. Uredbe), a u odnosu na predujam vrlo ograničena: „Iznimno, sud može stečajnom upravitelju odrediti isplatu predujma dijela nagrade ako stečajni dužnik nastavlja poslovati tijekom stečajnog postupka ili ako je na ročištu vjerovnika stečajnom upravitelju naložena izrada stečajnog plana“" (st. 3., čl. 2. Uredbe). O trećem bitnom problemu Uredba šuti iz čega proizlazi zaključak da se isplaćeni predujmovi uračunavaju u konačni iznos nagrade za rad makar stečajni upravitelj obavlja poslovodstvo i zastupstvo. Ostaje i nadalje da sud o nagradi odlučuje u rokovima po vlastitoj procjeni te da stečajni upravitelj u većini stečajnih postupaka, kreditira stečajne postupke, barem kada se radi o nagradi za njegov rad. Uredba, dakle, zanemaruje specifične okolnosti u kojima stečajni upravitelji obavljaju dužnost. To su broj i kvaliteta stečajnih upravitelja, način njihova imenovanja, odnos stečajnih sudaca i stečajnih upravitelja, naslijeđeni slučajevi prethodnog modela predstečajnih nagodbi, ogroman broj blokiranih subjekata, očekivana prosječna stečajna masa, zastupljenost procesa reorganizacije u odnosu na likvidaciju. Osnivanje posebnog Fonda za namirenje troškova stečajnoga postupka (Fond 2) trebalo bi, prema najnovijem rješenju hrvatske legislative, konačno riješiti kronični nedostatak novčanih sredstava za normalno funkcioniranje stečajnopravne procedure u dijelu koji se odnosi na troškove postupka. Iz Fonda se isplaćuju sredstva za namirenje troškova stečajnog postupka koji se ne mogu namiriti iz dva izvora: 1.) iz imovine dužnika i 2.) osiguranja predujma za namirenje troškova stečajnog postupka. Sredstva isplaćena iz Fonda za namirenje troškova stečajnog postupka jesu trošak stečajnog postupka i stečajni upravitelj ih je dužan vratiti u Fond za namirenje troškova stečajnog postupka nakon što u stečajnom postupku prikupi za to potrebna sredstva. Ipak, pitanje je kako će ovaj Fond funkcionirati u praksi jer dosadašnje iskustvo u provođenju stečajnih postupka u RH potvrđuje da Fond za pokriće troškova stečajnog postupka (Fond 1) iz čl. 39.a ,starog“ Stečajnog zakona iz 1996. nije ispunio očekivanja. Ako praksa u provođenju stečajnih postupaka dokaže da novi izvori financiranja Fonda 2. ipak nisu dostatni, to znači da se za njegove primarne korisnike (troškovi nagrade za rad i naknade troškova stečajnim

60 Jay, A., Harmer, R., „Insolvency office holders in south-eastern Europe“, u: EBRD - Law in transition 2007: Making an Insolvency system work, 2007. 
upraviteljima te najnužniji troškovi vezani za sređivanje arhivske građe i slično) ništa bitnije nije promijenilo u odnosu na otvorena pitanja uz Fond 1.

\section{UMJESTO ZAKLJUČKA ILI ČINJENICE I ZABLUDE O MOGUĆNOSTIMA STEČAJNE REFORME}

Danas je gotovo zaboravljeno da su današnje zemlje jakog tržišnog gospodarstva imale probleme s likvidnošću sredinom 20. stoljeća. Primjerice, velik broj njemačkih i austrijskih banaka i osiguravajućih društva, tijekom razdoblja nacionalsocijalizma bio je prisiljen uložiti znatan dio svojih financijskih sredstva u državne obveznice koje su postale bezvrijedne nakon rata. To je rezultiralo time da je cijeli jedan sektor bio insolventan. Kako bi se ponovno stvorio red, država je intervenirala, pa su austrijske banke i osiguravajuća društva bili izuzeti od obveze izdavanja financijskih izvještaja jer bi to podrazumijevalo obvezu podnošenja prijedloga za stečaj. To se može objasniti činjenicom kako su pojedine zemlje odredile različite ciljeve i svrhe stečajnih propisa pa su pravila o stečaju bila primjenjivana u pravnoekonomskom ambijentu u kojem su mnoga pitanja pravnog i ekonomskog života bivala regulirana neinstitucionalno, a zakonske odredbe, pa i one o stečaju, imale su samo funkciju instrumenta za provođenje političkih odluka. Neke zemlje, poput Češke, u počecima tranzicije prvo su odgodile primjenu stečajnog zakona, oslanjajući se na brzu privatizaciju. Druge zemlje, poput Mađarske, usredotočile su se na primjenu stečajnog zakona kao sredstva pripreme za privatizaciju, a $\mathrm{RH}$ se pozicionirala negdje u sredini. ${ }^{61}$ Naime, iz definicija danih u prvim člancima SZ-a iz 1997. (NN, 44/96) jasno se vidi cilj tada novog stečajnog postupka: razlog za otvaranje stečajnog postupka je činjenica da je dužnik određen kao insolventan (dakle neminovnost kriterija); stečajni postupak ima za cilj da se potraživanja vjerovnika u najvećoj mogućoj mjeri namire (dakle vjerovnici su postali aktivni sudionici postupka), a pravila stečajnog postupka postavljena su da bi se ostvario navedeni cilj (postojanje jasnijih rokova u postupku). Uzimajući u obzir utjecaj koji stečajni propisi imaju na pojedince i na društvo u cjelini, nastojanja za poboljšanje njihove kvalitete potpuno su razumljiva, a i nužna. Stoga je od svog donošenja Stečajni zakon mijenjan i dopunjavan više puta u cilju unapređivanja sustava stečajnopravne zaštite. Međutim, treba biti svjestan toga da mnoga rješenja nisu idealna, već su nametnuta trenutnim (političkim) okolnostima. Primjer je svakako ZFPPN. Ipak, možda je i najveći problem u tome da se danas od stečajnog postupka nerijetko očekuje ispunjenje više inkompatibilnih ciljeva. $\mathrm{S}$ jedne strane, postoji tendencija očuvanja radnih mjesta, a istovremeno se omogućuje i teži učinkovitijem nastavku poslovanja subjekta kroz neki od oblika reorganizacije!? S druge strane, ekonomski učinci SZ-a moraju biti takvi da potencijalni ulagači i drugi subjekti na tržištu znaju

61 Balcerowicz, E., Hoshi, I., Mladek, J., Novak, T., Sinclair, A., Szanyi, M., „Downsizing as an Exit Mechanism: Comparing the Czech Republic, Hungary, and Poland“", in: Balcerowicz, L., Gray, C. W. and Hoshi, I. (eds.), Enterprise Exit Processes in Transit Economies. Downsizing, Workouts, and Liquidation, Budapest: Central European University Press, 1998. 
što ih očekuje i u krajnjoj liniji predvide rizik poslovanja, pa je opravdano postaviti pitanje pravne nesigurnosti pogotovo zato što rezultati dosadašnjih novela stečajnih propisa pokazuju kako posljedice okončanih stečajnih postupaka nisu u funkciji zadanih ciljeva, namjera i opredjeljenja zakonodavca kao ni tržišta. Cilj najnovijih revizija stečajnog zakonodavstva iz 2015. jest osigurati jednostavno i fleksibilno upravljanje postupkom, s precizno određenim rokovima i jasnim posljedicama poduzetih radnji, preciznije definirati razloge za pokretanje stečajnog postupka, skratiti rokove vođenja postupka, pružiti bolju zaštitu vjerovnika i na potpuno drugačiji način regulirati postupak reorganizacije stečajnog dužnika. Također, može se navesti i to da je uloga suda sada da donosi sudske odluke prije nego poslovne te je omogućena veća samostalnost i odgovornost stečajnim upraviteljima, precizirana je procedura unovčenja imovine kao i reguliranje stečaja $s$ međunarodnim/ prekograničnim elementom. Ono što se mora ponovno istaknuti jest potpuno kvalitativno drugačije uređenje postupka reorganizacije. Dakle, iako se usvojenim propisima formalno ne mogu uputiti bitne primjedbe, odsustvo kolektivne strategije vjerojatno je uzrok tomu što oko reforme (kroz primjenu zakona) nije bilo moguće okupiti djelotvorne reformske snage. Tu dolazimo do ključnog zaključka kako problemi koji onemogućavaju učinkovitiji stečajni postupak odnosno ostvarenje cilja stečajnog postupka nisu oni vezani uz tekst zakona, već se nalaze u primjeni i/ili izvan samog stečajnog okvira. Možda je i najočigledniji primjer navedene teze kako reforma nije bila višestrana činjenica da zakonodavac nije predvidio učinke i posljedice koje će zakonske izmjene proizvesti te uslijed toga nije niti pripremio pravosudni sustav da spremno dočeka povećani priljev stečajnih predmeta čime se opet otvorilo pitanje (ne)mogućnosti ostvarenja ciljeva stečajnog postupka.

\section{Literatura:}

Armour, J., Cumming, D., „Bankruptcy law and entrepreneurship“, American Law and Economics Review, vol. 10, 2008., str. 303-350.

Balcerowicz, E., Hoshi, I., Mladek, J., Novak, T., Sinclair, A., Szanyi, M., „Downsizing as an Exit Mechanism: Comparing the Czech Republic, Hungary, and Poland“, in: Balcerowicz, L., Gray, C.W. and Hoshi, I. (eds.), Enterprise Exit Processes in Transit Economies. Downsizing, Workouts, and Liquidation, Budapest: Central European University Press, 1998.

Baltić, M., Načela evropskog stečajnog prava sa posebnim osvrtom na evropsku regulativu o stečajnim postupcima, Centar za pravo Evropske unije i Udruženje za pravo Evropske unije, Beograd, vol. 5, 2003., no. 1-3, str. 43-63.

Barbić, J. (ur.), Hrvatsko insolvencijsko pravo, Hrvatska akademija znanosti i umjetnosti (HAZU) - Znanstveno vijeće za državnu upravu, pravosuđe i vladavinu prava, Zagreb, 2014.

Barbić, J., „Utjecaj njemačkog prava na stvaranje hrvatskog prava društva“, Zbornik radova Pravnog fakulteta u Splitu, vol. 44, 2007., br. 3-4, str. 339-363. 
Beugelsidjk, S, R., Maseland, R., Culture in Economics - History, Methodological Reflections and Contemporary Applications, Cambridge University Press, Cambridge UK, 2010.

Bodul, D. et al., „Institut stečajnog plana i predstečajne nagodbe u hrvatskom pravu u kontekstu regionalnog i međunarodnog razvoja“, Podjetje in delo, 2013., br. 4, str. 230. et seq.

Bodul, D. et al., „Pravnopovijesni i poredbenopravni prikaz razvoja stečajnog postupka“, Zbornik Pravnog fakulteta Sveučilišta u Rijeci, vol. 34, 2013., br. 2, , str. 911-941.

Bodul, D., et al., „O načelu socijalnog postupanja u stečajnom postupku s naglaskom na prava radnika“, Zbornik Pravnog fakulteta Sveučilišta u Rijeci, vol. 34, 2013., no. 1, str. $525-560$.

Bodul, D., et al., „Stečaj nad kreditnim institucijama, isplatni redovi i mogućnost reorganizacije“, Pravo i porezi, 2013., br. 5, str. 13 -15.

Bodul, D., et al., „Položaj stečajnog dužnika u postupcima javne nabave - de lege lata rješenja, pogled u europsko i konvencijsko pravo i pravci promjene“, Zbornik Pravnog fakulteta Sveučilišta u Rijeci, vol. 37, 2016., br. 2, str. 791-805.

Bodul, D., Grbić, S., „Otkaz ugovora o radu u praksi Europskog suda za ljudska prava“, časopis Radno pravo, 2014., br. 9., str. 40-50.

Bujišić-Petrović, B., „Nacionalna država i Nadnacionalni biznis“, u: Biznis i država, Institut društvenih nauka - Centar za ekonomska istraživanja, Beograd, 2006., str. 281-288.

Claessens, S., Klapper, L. F., Bankruptcy around the World: Explanation of its Relative Use, World Bank Publicity Research Working Paper 2865., 2002.

Čuveljak, J., „Neprimjenjivost Pravilnika o ovršnoj prodaji nekretnina kod prodaje u stečajnom postupku“, Pravo u gospodarstvu, vol. 3, 2015., br. 54, str. 375. et seq.

Davydenko, S. A., Franks, J., „Do Bankruptcy Codes Matter? A Study of Defaults in France, Germany, and the U.K.“, The Journal of Finance, vol. 63, 2008., str. 565-608.

Djankov, S., Hart, O., McLiesh, C., Shleifer, A., „Debt Enforcement Around the World“, Journal of Political Economy, vol. 116, 2008., str. 1105-1150.

European Commission, Proposal for a Regulation of the European Parliament and of the Council amending Council Regulation (EC) 1346/2000 on insolvency proceedings, Strasbourg, 12. XII. 2012., COM (2012.), 012/0360 (COD), 744 final).

Garašić, J., „Stečajni plan nakon izmjena i dopuna Stečajnog zakona 2012.“, u: Djelotvorna pravna zaštita u pravičnom postupku - Izazovi pravosudnih transformacija na jugu Europe, Liber amicorum Mihajlo Dika, Zbornik radova u čast 70. rođendana prof. dr. sc. M. Dike (ur. A. Uzelac, J. Garašić, A. Maganić), Pravni Fakultet, Zagreb, 2013., str. 490. et seq.

IMF, Orderly and Effective Insolvency Procedures, Washington, DC, 1999. 
Jackson, T. H., „Bankruptcy, Non-Bankruptcy Entitlements, and the Creditors’ Bargain“, Yale Law Journal, vol. 91, 1982., str. 857.

Janeš, Z., „Državne potpore i predstečajna nagodba“, Računovodstvo i financije, 2012., br. 12 , str. 46 .

Jay, A., Harmer, R., „Insolvency office holders in south-eastern Europe“, u: EBRD - Law in transition 2007: Making an insolvency system work, 2007.

Jelčić, B., Financijsko pravo i financijska znanost, Narodne novine, Zagreb, 2008., str. 50. et seq.

Lee, S.-H., Yamakawa, Y., Peng, M., Barney, J., „How do bankruptcy laws affect entrepreneurship development around the world?", Journal of Business Venturing, vol. 26, 2011., str. 505-520.

Majstorović, D., „Stečajna kaznena djela“, Hrvatski ljetopis za kazneno pravo i praksu, vol. 14., 2007., br. 2, str. 643-671.

Martin, N., „Common-Law Bankruptcy Systems: Similarities and Differences“, American Bankruptcy Institute Law Review, vol. 11, 2003., str. 367.

Martin, N., ,The Role of History and Culture in Developing Bankruptcy and Insolvency Systems: The Perils of Legal Transplantation“, Boston College International \& Comparative Law Review, vol. 28, 2005., no. 1, str. 1-78.

Mihelčić, G., u suradnji s Kontrec, D., Komentar Ovršnog zakona, Organizator, Zagreb, 2015., str. 49. OECD, Creditor Rights in Insolvency Procedure, Sydney, November 1999.

Radović, V., „Stečajni isplatni redovi“, Pravni život, vol. 54, 2005., str. 87-106.

Radulović, B., Jovanović, A., „Stečaj, poverenje i nacionalna kultura“, Ekonomska politika Srbije u 2015., B. Živković, B. Cerović (ured.), Ekonomski fakultet Univerziteta u Beogradu i Naučno društvo ekonomista Srbije, 2015., str. 133-152.

Rasmussen, R. K., „An Essay on Optimal Bankruptcy Rules and Social Justice“, University of Illinois Law Review, vol. 1, 1994., str. 1-43.

Raymond Azar, Z., Ziad, „Bankruptcy Policy: A Review and Critique of Bankruptcy Statutes and Practices in Fifty Countries Worldwide", Cardozo Journal of International and Comparative Law, vol. 16, 2008, no. 1, str. 282.

Šimundić, M. Stečajni postupak u praksi, Sudačka mreža: http://www.sudacka-mreza.hr/ doc/sr/radovi/ Mladen Simundic_-_Stecajni_postupak_u_praksi.pdf (12. X. 2015.).

Šverko Grdić, Z., Radolović, J. i Bagarić, L., „Solventnost poduzeća u Republici Hrvatskoj i u Europskoj uniji“, Ekonomski pregled, vol. 60, 2009., no. 5-6, str. 250. et seq.

The World Bank Symposium, Building effective insolvency system- transcript, Washington, D.C.,1999. 
Učinci predstečajnih nagodbi - Izvješće FINA-e prezentirano Hrvatskom saboru 17. travnja 2015.

UNCITRAL, Legislative Guide on Insolvency Law, 2004.

Virgos, M., The 1995 European Community Convention on Insolvency Proceedings: An Insider's View, Kluwer Law International, The Hague, 1998., str. 1. et seq.

Direktiva 2008/94/EZ Europskog parlamenta i Vijeća od 22. listopada 2008. o zaštiti zaposlenika u slučaju insolventnosti njihovog poslodavca (OJ 283/36, 28. X. 2008.).

European Commission, Proposal for a Regulation of the European Parliament and of the Council amending Council Regulation (EC) 1346/2000 on insolvency proceedings, Strasbourg, 12. XII. 2012., COM (2012.), 012/0360 (COD), 744 final).

Europska konvencija za zaštitu ljudskih prava i temeljnih sloboda, NN-MU, 18/97, 6/99, 14/02, 13/03, 9/05, 1/06 i 2/10.

Jedinstvena metodološko-nomotehnička pravila za izradu akata koje donosi Hrvatski sabor, NN, 74/15.

Konačni prijedlog Zakona o financijskom poslovanju i predstečajnoj nagodbi PZE 138, str. 46 , odj. 4.

Ovršni zakon, NN, 112/12, 25/13 i 93/14.

Stečajni zakon, NN, 71/15.

Uredba o kriterijima i načinu obračuna i plaćanja nagrade stečajnim upraviteljima, NN, $105 / 2015$.

Uredba o osnivanju Imunološkog zavoda, NN, 91/15.

Uredbe Vijeća (EC) broj 1346/2000, od 29. svibnja 2000. o stečajnim postupcima (OJ 2000 L 160) izmijenjene Uredbom 603/2005 od 12. travnja 2005. (OJ 2005 L 100).

Zakon o financijskom poslovanju i predstečajnoj nagodbi, NN, 108/12, 144/12, 81/13, 112/13, 71/15 i 78/15.

Zakon o osiguranju depozita, NN, 82/15.

Zakon o osiguranju potraživanja radnika u slučaju stečaja poslodavca, NN (114/03), 86/08, 80/13 i 82/15.

Zakon o radu, NN, 93/14.

Zakon o stečaju potrošača, NN, 100/15 stupa na snagu 01. siječnja 2016.

Zakon o sudskom registru, NN, 1/95, 57/96, 1/98, 30/99, 45/99, 54/05, 40/07, 91/10, 90/11, 148/13 i 93/14.

Zakon o rokovima ispunjenja novčanih obveza, NN, 125/11. 
Zakona o obveznim odnosima, NN, 35/05 i 41/08.

Zakon o trgovačkim društvima, NN, 34/99, 121/99, 52/00, 118/03, 107/07, 146/08, 137/09, 125/11, 152/11, 111/12, 68/13 i 110/15.

Zakon o kreditnim institucijama, NN, 159/13, 19/15 i 102/15.

Interfina and Christian della Faille d'Huysse protiv Belgije, odluka, 4. svibnja 1987., br. 11101/84.

Rješenje Visokog trgovačkog suda Republike Hrvatske, posl. br. 66. Pž-5577/10-3 od 28. IX. 2010.

S.p.r.1. ANCA and Others protiv Belgije, odluka, 10. prosinca 1984., Decisions and Reports 40.

Stran Greek Refineries i Stratis Andreadis protiv Grčke, presuda, 9. prosinca 1994., Serija A, br. 301-B.

Prijedlog za ocjenu ustavnosti, br. U-I-2806/15.

\section{PLURALITY OF AIMS IN BANKRUPTCY PROCEEDINGS}

The functionalization of Croatian Bankruptcy Law (and proceedings) must be comprehended as a wider process than the usual reception of foreign legal institutes and ad hoc solutions for salvaging current economic and social consequences. Taking into account the eclecticism of the approach of amendments to bankruptcy regulations, posing the following question is justified: What is the aim of bankruptcy proceedings and in whose interest are it? This in particular comes to the fore given that, in the practical application of bankruptcy regulations, the interests of several concerned parties are diffracted. These are those of government, creditors both ordinary and privileged, employees, liquidators, former owners and wider social interests. Therefore, the author, by analysing the interests of the mentioned parties and the bodies and participants of the bankruptcy proceedings, points out the limited opportunities for achieving normatively defined legal bankruptcy goals. We certainly believe that it is important to emphasise that the space we have here does not allow a detailed analysis of this problem area. So, we are forced to limit ourselves exclusively, according to the author, to some aspects of new bankruptcy regulations which best define the subject of this paper.

Key words: new bankruptcy regulations, defined aims, practical implications of bankruptcy regulations 